\title{
Foreword to 'Multiscale structural biology: biophysical principles and mechanisms underlying the action of bio-nanomachines', a special issue in Honour of Fumio Arisaka's 70th birthday
}

\author{
Damien Hall $^{1,2}$ (D) $\cdot$ Junichi Takagi $^{1} \cdot$ Haruki Nakamura ${ }^{1}$
}

Received: 10 January 2018 / Accepted: 29 January 2018 / Published online: 2 March 2018

(C) International Union for Pure and Applied Biophysics (IUPAB) and Springer-Verlag GmbH Germany, part of Springer Nature 2018

\begin{abstract}
This issue of Biophysical Reviews, titled 'Multiscale structural biology: biophysical principles and mechanisms underlying the action of bio-nanomachines', is a collection of articles dedicated in honour of Professor Fumio Arisaka's 70th birthday. Initially, working in the fields of haemocyanin and actin filament assembly, Fumio went on to publish important work on the elucidation of structural and functional aspects of T4 phage biology. As his career has transitioned levels of complexity from proteins (hemocyanin) to large protein complexes (actin) to even more massive bio-nanomachinery (phage), it is fitting that the subject of this special issue is similarly reflective of his multiscale approach to structural biology. This festschrift contains articles spanning biophysical structure and function from the bio-molecular through to the bio-nanomachine level.
\end{abstract}

\section{Introduction}

Professor Fumio Arisaka is one of the most well-known biophysical scientists in Japan. Holding senior offices in the Asia Pacific Protein Association, the Protein Science Society of Japan and the Biophysical Society of Japan, he has been one of the mainstays of Japanese scientific practice and international engagement for the last four decades. He has promoted scientific education (via extensive teaching, translation of foreign textbooks and writing of original scientific textbooks), championed the development and usage of biophysical methods concerned with the evaluation of structure and

This article is part of a Special Issue on 'Biomolecules to Bionanomachines-Fumio Arisaka 70th Birthday' edited by Damien Hall, Junichi Takagi and Haruki Nakamura

Damien Hall

damien.hall@protein.osaka-u.ac.jp

Junichi Takagi

takagi@protein.osaka-u.ac.jp

Haruki Nakamura

harukin@protein.osaka-u.ac.jp

1 Institute for Protein Research, Osaka University, 3-1- Yamada-oka, Suita, Osaka 565-0871, Japan

2 Research School of Chemistry, Australian National University, Acton, ACT 2601, Australia function of biomolecules in solution (light scattering and analytical ultracentrifugation) and made major contributions in the area of structural biology of bacterial viruses (T4 phage). Aside from his important contributions to both the structure and practice of science, he has lived a genuinely fascinating life that should be of interest to the readers of Biophysical Reviews. In this Foreword, we will try and tell some of Fumio's scientific and personal story, with the caveat that we (as scientists) probably lack the necessary biographical talents to fully do justice to it. However, despite our literary shortcomings, we think that the story of Fumio's life and scientific achievements carry within them sufficient excitement ${ }^{1}$ to make up for our imperfect exposition.

Suggestive of the regard in which Professor Arisaka is held (both in Japan and overseas), this Special Issue is the largest (in terms of the number of contributed articles) in the history of the Biophysical Reviews journal with 57 articles. Immediately following this Foreword, there is a short piece by Fumio himself (Arisaka 2018) and a series of topical letters from scientists describing personal recollections/viewpoints about Prof. Fumio Arisaka's career and life (Rossmann 2018; Takeda 2018 and Schuck 2018). ${ }^{2}$ The remaining

\footnotetext{
${ }_{1}^{1}$ Particularly for younger scientists at the beginning of their career journey.

${ }^{2}$ Also included in this 'Letters to the Editor' front-section is a scientific letter relating to the topic in fluorescence resonance energy transfer (FRET) analysis [Yamaguchi et al 2018].
} 
scientific contributions fall under the collective designation of 'multiscale structural biology' which we define as follows,

- Multiscale structural biology: Elucidation of biologically relevant structural information over a size scale ranging from the cellular to molecular and atomic levels via the combination of experiments with computer modelling and simulation.

Of the articles fitting into this category, we have further sub-divided them into three sections

(i) biomolecules and biophysical principles: in which we include contributions pitched at the level of molecular characterization or modelling based on basic physical principles (Soares da Costa et al. 2018; Arai 2018a; Senda and Senda 2018; Kato et al. 2018a; Arakawa 2018; Mizohata et al. 2018; Mio and Sato 2018; North et al. 2018; Unzai 2018; Furutani 2018; Rivas and Minton 2018; Akazawa-Ogawa et al. 2018; Uchiyama et al. 2018; Nagai et al. 2018; Ando 2018; Sawitri et al. 2018; Ogawa and Hirokawa 2018; Okamoto et al. 2018; Fujiwara and Masuda 2018; Sahlan et al. 2018; Takahashi et al. 2018; Mitsutake and Takano 2018),

(ii) molecular assemblies: where we include articles examining the mechanism of, and functional effects produced by, changes in biomolecular quaternary structure (Arai 2018b; Toda et al. 2018; Yagi et al. 2018; Kato et al. 2018b; Kohda 2018; Urade et al. 2018; Sekiya et al. 2018; Sasahara 2018; Hyman and van Raaij 2018; Kuroda 2018; Nogi 2018; Goto et al. 2018; Song 2018; Yamaguchi and Kuwata 2018; Chatani and Yamamoto 2018),

(iii) bio-nanomachines: this section includes reviews describing a number of different examples of super-scale molecular assemblies with a focus on placing their behaviour at the life/machine interface (Fig. 1) (Inaba and Ueno 2018; Mima 2018; Nakagawa et al. 2018; Serwer et al. 2018; Quax and Daum 2018; Phillips-Jones and Harding 2018; Dowah and Clokie 2018; Katoh and Satoh 2018; Ekimoto and Ikeguchi 2018; Kitao and Hata 2018; Mizobata and Kawata 2018; Imada 2018; Nishikawa and Kinjo 2018; Tayo 2017).

To each of the Guest Editors, Fumio has played a different role. To DH, he was a much appreciated supervisor (2007) and continuing academic collaborator (2008-present); to JT, he was a friend and trusted academic colleague whilst working together at Tokyo Institute of Technology (1991-1998) (and continues to be an invaluable advisor regarding the theoretical and practical aspects of analytical ultracentrifugation), whilst to $\mathrm{HN}$, he was a university colleague, fellow committee member and co-author of a series of textbooks. However, to all,
Fumio has been a loyal friend and an extremely stimulating scientific discussion partner. It is with great pleasure and pride that we have collectively assembled this special issue in honour of Fumio's 70th birthday. We would like to thank all contributors for the kindness and perspicacity they have displayed in meeting the special issue deadline.

Our goal in this Editorial is to describe a little of Fumio's life story and bring his scientific approach and academic achievements to the fore. To achieve the latter, we will highlight a number of papers written at different stages of Fumio's career. To achieve the former, we have written a brief biographical sketch of Fumio's life both inside and outside of science. The two are intertwined in the form of this mini-scientific biography.

\section{Family history}

Fumio's family history can be traced back to the southern part of Nagano prefecture (located in central Japan) from around the $1500 \mathrm{~s}^{3}{ }^{3}$ In the late $1500 \mathrm{~s}$, the Arisaka household came into conflict with the rising power of Takeda Shingen, the Daimyo (Great Lord) of the region, and were forced further east, first into the Gunma province from which they then migrated into the Kanto area (Tokyo and its surrounds). From the early 1700s, the Arisakas can be tied to the service of the Tokugawa, the most powerful of all of Japan's Shogunates, ${ }^{4}$ who ruled Japan from 1604 to 1868 . In this power structure, Fumio's ancestors served as mid-level retainers, known as gokenin of the bushi (Samurai) class. In this role, Fumio's forebears regulated canal trade in the Kanto area receiving annually $30 \mathrm{koku}$ (rice bags) for their services. As a retainer of the last Shogun (Tokugawa Yoshinobu), Fumio's great grandfather left the capital to move with him to Shizuoka after his resignation in 1867. This return of political power to the Emperor was the symbolic start of the Meiji restoration period. Four years later, Fumio's great grandfather was invited back to Tokyo to serve as an officer of the Kunai-sho (Imperial Household Ministry).

With the transition to Imperial rule from 1868, the Arisaka family supported the new Meiji government in developing many of the academic, military and cultural institutions that define modern Japan. Fumio's Grandfather Shozo Arisaka (1868-1941) studied engineering at the Imperial University in Tokyo and was one of the early overseas military attaches for the Japanese navy (Fig. 2). Indeed, from overseas assignments to France, Shozo helped to incorporate modern naval gunnery technologies in the developing Japanese imperial

\footnotetext{
${ }_{3}^{3}$ It is perhaps from this area that the Arisaka name is derived for which the Chinese kanji characters literally translate as ari 'exist' and saka 'slope'.

${ }^{4}$ In 1192, Minamoto Yoritomo of Kamakura (Kanto region) obtained the highest political power (Shogun) from the Emperor who resided in Kyoto. This situation lasted until 1333 when the Shogunate (or Bakufu) moved to the Kansai (Osaka/Kobe) area once again. In 1603 Tokugawa Ieyasu moved the Bakefu to Edo (Tokyo). The present Emperor's palace in Tokyo was inherited from the Tokugawa family and was originally called Edo Castle.
} 
Fig. 1 Example of a bionanomachine reviewed in this series (Quax and Daum 2018).

Virus-associated pyramids (VAPs) are built by the selfassembly of a single type of small $10 \mathrm{kDa}$ viral protein known as pVAP. After deposition of the VAP within the bacterial membrane, a transition from a closed to an open conformation promotes conditions amenable to viral lysis. The multiscale nature of the VAP assembly and its resultant ability to perform work associated with an allowable structural transition captures the overall spirit of this special issue. Fig. 1a, c, e, g Cryo-EM obtained tomographic slices whilst Fig. 1b, d, f, $\mathbf{h}$ describe the segmented, surface-rendered volumes of the VAPs in the membrane of infected $S$. islandicus cells. VAPs are either closed (a-d) or open $(\mathbf{e}-\mathbf{h})$. The cell membrane is blue whilst the VAP is yellow (scale bars, $200 \mathrm{~nm}$ ) (figure taken from Daum et al. 2014). Self-assembly of the general membrane-remodeling protein PVAP into sevenfold virus-associated pyramids. Proceedings of the National Academy of Sciences, 111(10), pp.3829-3834]
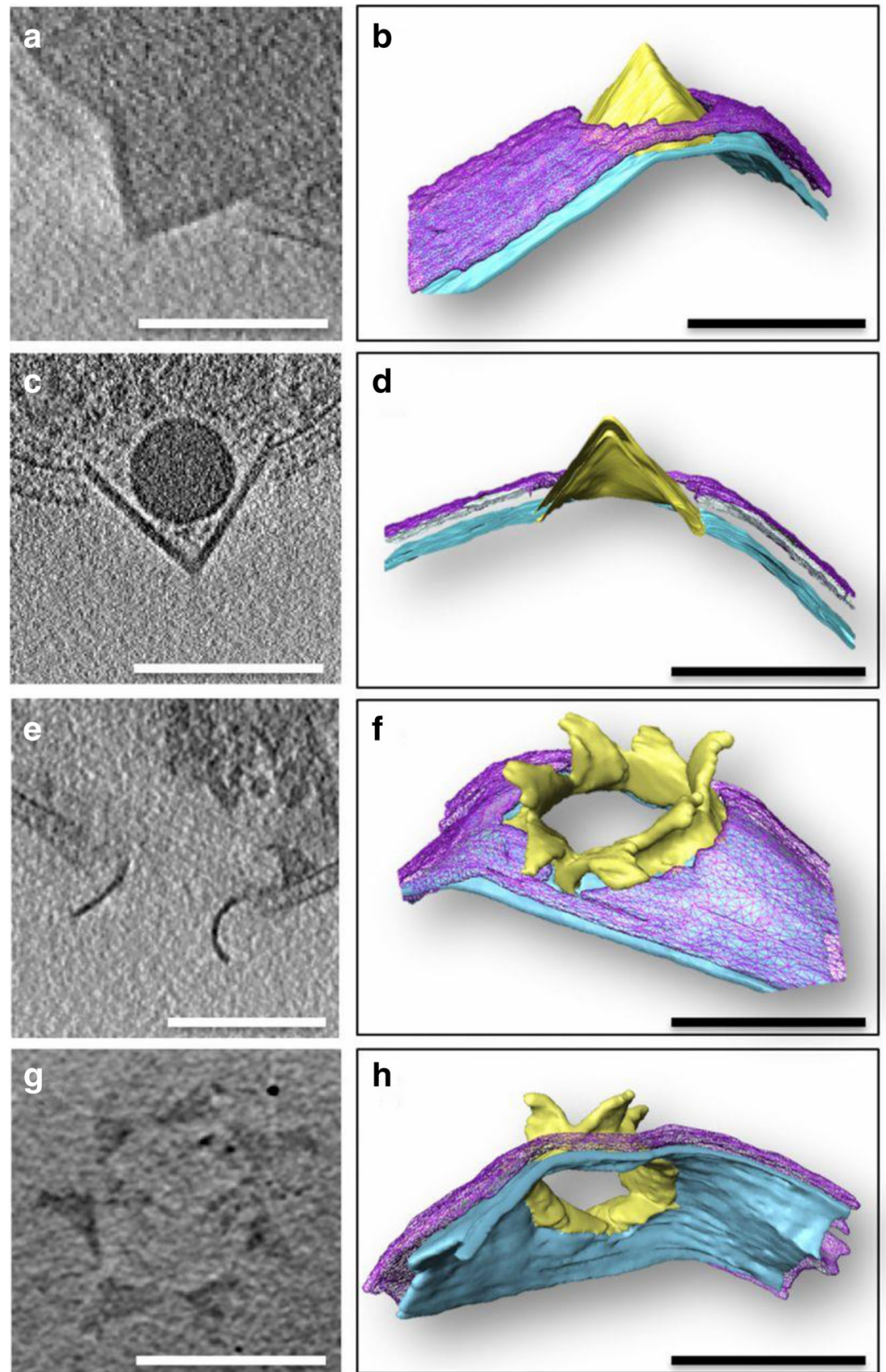

navy. In later life, Shozo Arisaka rose to become Commander of the Japanese Imperial Naval Shipyard located at Etajima Island, Kure, Hiroshima. Shozo Arisaka later became Professor of Engineering at Tokyo University and was also appointed as a member of the Japanese Academy. ${ }^{5}$ Aside from his background in engineering, Shozo Arisaka was also famous for a series of archaeological discoveries (made in his youth) of ancient pottery from the Jomun and Yayoi periods

\footnotetext{
${ }^{5}$ Indeed Shozo was awarded the Gakushiin Onshi sho (Japan Academy Prize) based on his Heiki-ko - a three volume series on the history of armaments (Arisaka 1936).
}

stretching back to 13,000 years $b c e^{6}$ (Gaillard 2004). Shozo's love of both history and science was shared by his family. His brother in law, Chiyomatsu Ishikawa, was the student of, and translator for, Edward Sylvester Morse, the scientist credited with disseminating Charles Darwin's and Alfred Wallace's theories of evolution throughout Japan (Onaga 2015). The

\footnotetext{
${ }^{6}$ As an interesting footnote Shozo Arisaka's co-discovery of this pottery with Professor Shogoro Tsuboi, then Chair of Archaeology at Tokyo University, was revealed to Fumio by Tsuboi's grandson, when he was teaching Fumio Xray crystallography during his undergraduate degree at Tokyo University 80 years later.
} 
Fig. 2 Collage of personal family photos from the Arisaka family. (Top left) Fumio's Grandfather Shozo Arisaka (1868-1941) (ca. 1930). (Top right) Fumio's Father Iwao Arisaka (1903-1970) playing bass along with his large family (ca. 1964). (Centre left) Fumio Arisaka as a young boy off on his way to school (ca. 1954). (Upper centre right) Fumio with his wife Hiroko and four sons (ca. 1992). (Lower centre right) Fumio surrounded by former students and staff members on the occasion of his last lecture (2014). (Bottom left) Fumio performing the flute with string accompaniment (2014). (Bottom right) Fumio standing next to the Tokyo Institute of Technology Campus where he worked for 25 years $(2014)$
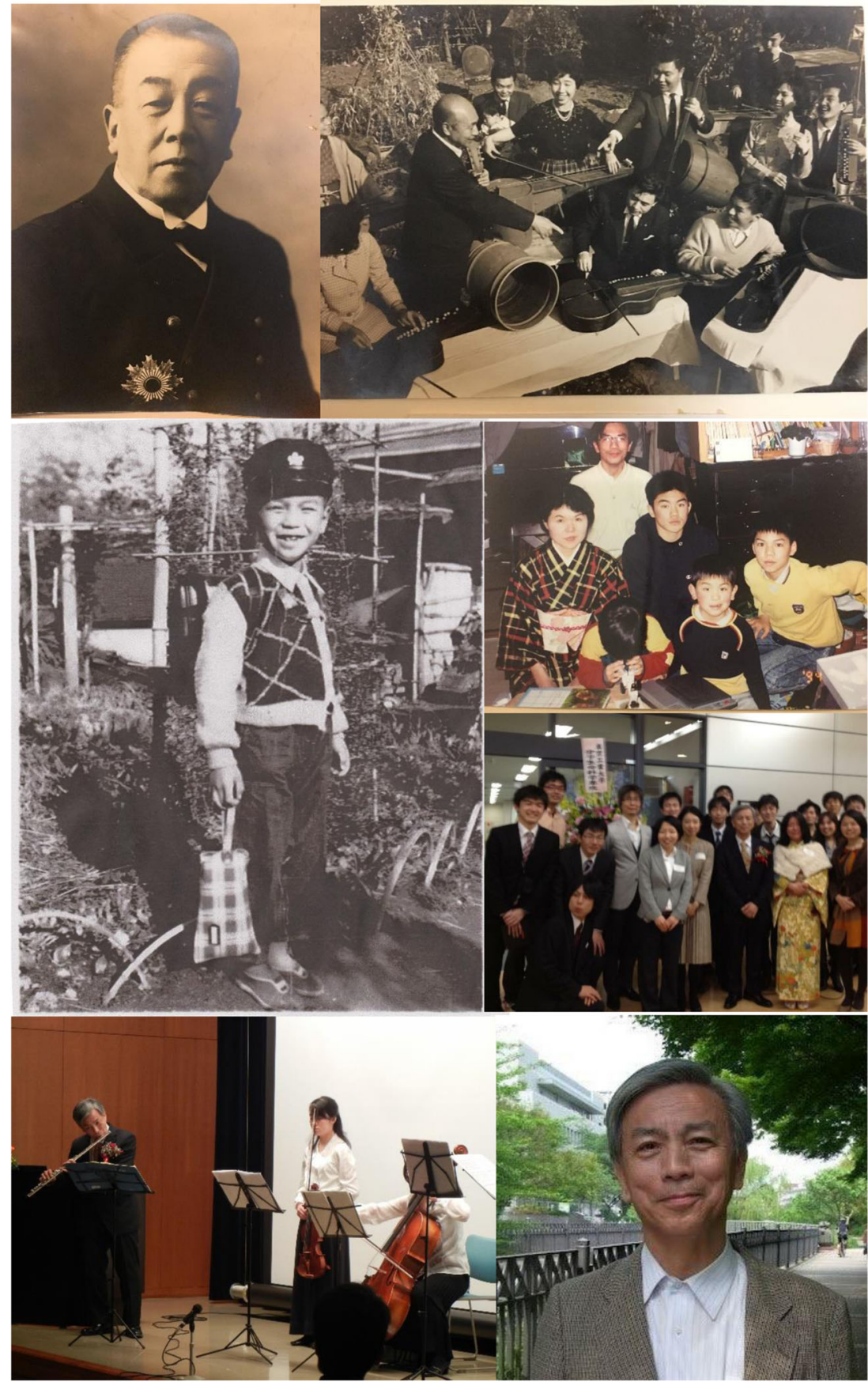

same Chiyomatsu Ishikawa later became a Professor at the School of Agriculture at the University of Tokyo.

Shozo Arisaka had seven children. Among them, his three sons Yoshihiko, Hideyo and Iwao were especially close. Yoshihiko (1905-1986) was a cellist and a music critic who helped contribute to the founding of Japanese Philharmonic Orchestra in $1956 .^{7}$ Hideyo (1908-1952) went on to become a well-known linguist in the field of phonology. Making important

${ }_{7}^{7}$ Fumio's love of music may perhaps come from the influence of his uncle Yoshihiko. discoveries from his study of the Manyo-shu and Kojiki (two of the founding historical documents of Japan), his name is remembered in the "Arisaka-law" ${ }^{8}$ which states the strict rules of usage for primary vowels in the Japanese language (Frellesvig 2010). The third of these close-knit trio was Fumio's Father, Iwao Arisaka (1903-1970). Iwao was a career military officer who, as a young man, studied naval engineering at the Kure Imperial Navy Shipyards at which his Father Shozo commanded. After

\footnotetext{
${ }^{8}$ Indeed Hideyo was also awarded the Gakushiin Onshi sho (1952, Japan Academy Prize) based on his studies on "The history of Japanese Phonology".
} 
working in the Navy for several years, he was seconded to Tohoku University as a Lieutenant Colonel, a time during which he received a formal degree in engineering whilst working together with Professors Yagi and Uda - the team widely credited with developing the first functional directive antenna ("Yagi antenna") for radar systems (Huurdeman 2003). As a Lieutenant, Iwao was seconded to Princeton as a military attache to study American developments in their early progress into the technology of radar. Having seen the advances in radar development in the USA, he felt it essential to also develop and refine this technology for military usage in Japan. Aside from his engineering activities, Iwao saw active service in the latter half of the war. Serving on the aircraft carrier 'Shokaku', he was stranded at sea for nearly 2 days after his ship was sunk in 1944 by the American submarine the 'USS Cavalla' during the largest ever aircraft carrier battle, known (in English) as the Battle of the Philippine Sea (Stille and Bryan 2012). Eventually rescued by the Japanese Navy, Iwao Arisaka returned to military service and finished the war at the rank of Naval Colonel.

\section{Early childhood and schooling}

Fumio Arisaka was born in April, 1948, just 3 years after the conclusion of the second-world war. Fumio's early family life was characterized by privation, due to a combination of the general devastation heaped upon Japan's infrastructure and economy by the ally invasion and the 'de-imperialization' program enacted by the occupying forces which affected Fumio's family with particular force due to his Father's rank as a Naval Colonel. This latter aspect led to Fumio's family losing the inherited lands and former entitlements bestowed to them first under the Shogunate and then later Imperial rule.

When Fumio's Father was released from the allied forces decommissioning base at Yokosuka at the conclusion of the war things looked bleak. His first wife had tragically died during the war leaving him with five children to care for. This situation was coupled with lack of employment due to an occupation force's rule that prevented any former senior military officers from taking on a government position for a period of 3 years. In spite of this grim situation, Iwao's luck took a turn for the better after being introduced to a young school teacher named Kotoko whom he soon married. With five children from his former marriage and two new children (Fumio being one of them) coming from his second, this union resulted in a large extended family with Fumio having three elder step brothers, two elder step sisters, and one younger brother. Despite the loss of privilege and large family to support, Fumio's childhood was nevertheless a happy one. Fumio's father set up a small business in electronics repairs that mostly involved repairing broken radios and (the then newly released) television set. Iwao's business was not particularly successful but, according to Fumio, this probably led to the rare situation in which his university-level science educated Father had time to instruct his children in their tours of the items in his workshop (physics and engineering), the observation of the stars at night (astronomy) along with their daily encounters with the plants and animals in the fields (biology). Alongside his school teacher mother's encouragement and instruction, these early lessons helped to propel Fumio's admission into the then top high school in Yokohama, Eiko Gakuen. Administered by German Jesuit priests, whom also made up a large number of the teaching staff, ${ }^{9}$ it was here that Fumio received his first formal training in physics and mathematics.

\section{University undergraduate}

University of Tokyo (1968-1972) Fumio was admitted to the University of Tokyo in 1968. With an initial intention to solely study the physical sciences, Fumio's plans were affected somewhat by student unrest (daigaku toso) and protests lead by the student activist zenkyoto and communist minsei movements (Kelman 2001). Upon attending a makeup summer class on introductory biology during this disrupted period, Fumio was both impressed and strongly influenced by his university biology lecturer, Prof. Koscak Maruyama, who taught metabolism and biological chemistry. Remembering this interest, in his final year, Fumio applied to Maruyama's laboratory for a fourth-year project and was assigned the topic of studying the effect of actomyosin fibre adsorption on lipid bilayer membrane pressure using a Langmuir surface balance-with these studies leading to Fumio's first publications (Maruyama et al. 1973). These studies are of particular interest when placed within context of the exciting breakthroughs in the field of actin filament protein science being made in Japan at that stage by Fumio Oosawa and colleagues (Oosawa and Kasai 1962; Oosawa and Asakura 1975).

\section{Postgraduate studies}

Masters degree at Tokyo University (1972-1974) After graduating from his undergraduate degree, Fumio continued to pursue his interest in biophysical chemistry by entering, in 1972, into a Masters Course in the laboratory of Prof. Haruhiko Noda. ${ }^{10}$ Fumio's project involved experimental and theoretical studies on the polymerization mechanism of the actin $G$ to $F$ transition with the ultimate aim of using experimental data gained from measurements of flow birefringence, the release of labelled inorganic phosphate from radiolabelled $[\gamma-32 \mathrm{P}]$ ATP and measurement of the length distributions of filamentous actin by electron microscopy to recover kinetic rate constants by directly fitting numerical solutions of the differential equation set for the Oosawa helical polymerization model (Fig. 3). Although

\footnotetext{
9 In later years Fumio's Father Iwao was also recruited as a teacher of physical sciences at the Eiko Gakuen School.

${ }^{10}$ After Fumio's undergraduate degree Prof. Koscak Maruyama left the University of Tokyo to take on a position at Kyoto University which lead to Fumio entering into the laboratory of the more senior Professor Haruhiko Noda.
} 
somewhat defeated by the lack of computing power available at that time, those studies (Arisaka et al. 1973; Arisaka et al. 1975) revealed both a keen intellect and strong physical intuition in his approach to tackling biological research problems.

Although not without its own benefits, as a result of it being much larger, Prof. Noda's laboratory had a tougher, more competitive edge to it, which prompted Fumio to contemplate a different laboratory for his Doctor's course (D.Sc.) studies. Upon the advice and encouragement of the new Noda laboratory jokyo (then Assistant Professor Atsushi Ikai), Fumio considered entering into a Ph.D. overseas. Assist. Prof. Ikai's list of positive reasons for going overseas were as follows,

(i) Improved chance for mastering English

(ii) A stronger bond is formed with your supervisor at the student vs. postdoctoral level.

(iii) Friends formed during $\mathrm{PhD}$ remain forever.

Upon consultation, Professor Noda provided a wellreasoned alternative point of view. The most important of the reasons given were,

(i) American systems of postgraduate training involve a lot more coursework and testing that may be hard for a nonnative English speaker. (ii) Those studying outside of Japan would miss out on the special structure that Japanese society is based on. In this system, each directly senior person, the senpai, has an obligation to assist their junior colleague, the kohai.

Weighing up the pros and cons, Fumio decided to take a chance and wrote to three biophysical chemists, based in America, inquiring about the chance of their supporting his future Ph.D. candidature. Although these three scientists, Charles Tanford, Serge Timasheff and Kensal Edward van Holde are all well known today, they were less famous at that time. Of the three, Prof. van Holde was the only scientist that could guarantee significant financial support, and so at the conclusion of his Master's Degree, Fumio set his sights on the Laboratory for Physical Biochemistry at Oregon State University.

However, prior to accepting the position, an important financial obstacle remained. Although Fumio had applied for a JSPS Scholarship support, its award was contingent upon a suitable English score. To achieve this, Fumio went back to his high school instructors at the Eiko Gakuen Jesuit School, and after a brief period, he both achieved a high score on the TOEFL test (Test of English as a Foreign Language) and passed the required interview section to receive the JSPS award. These monies paid for Fumio's air ticket (his first time on an aeroplane) as well as funding the first year of his $\mathrm{PhD}$ tuition and living costs.
Fig. 3 Kinetic analysis of actin polymerization kinetics in terms of the Kasai-Asakura-Oosawa helical growth model carried out by Fumio during his Masters Course. (Top) Time-dependent length distribution of F-actin microfilaments formed from G-actin measured by transmission electron microscope (taken with permission from Fig. 3 of Arisaka et al. 1975). (Bottom) Set of interrelated differential equations (reflecting a nucleated growth polymerization scheme) used by Fumio to try and directly fit the length distribution data shown above (reproduced from Arisaka et al. 1975)

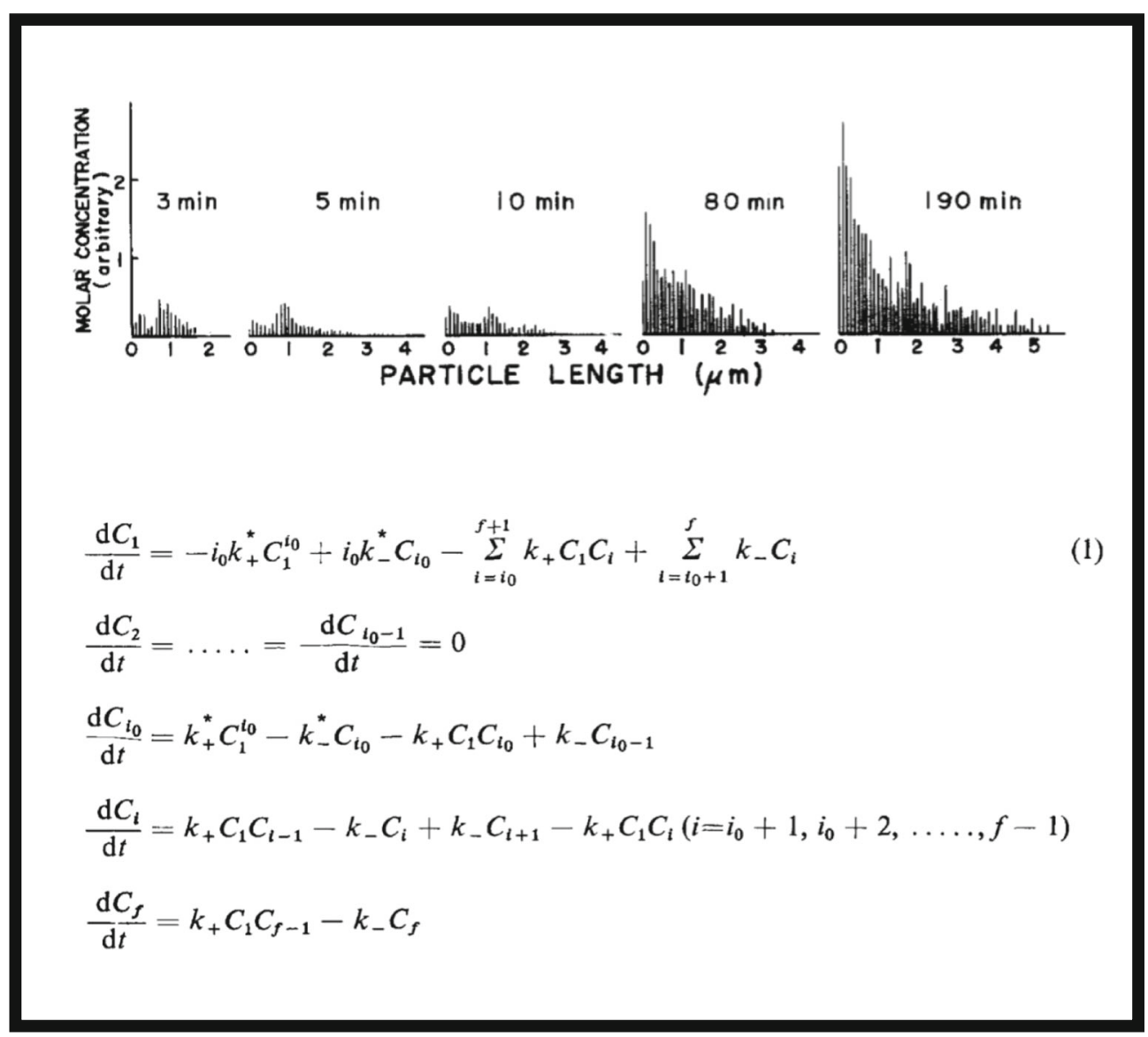


A PhD (not a DSc) in the USA (1974-1977) Upon arriving in van Holde's laboratory in September of 1974, Fumio was given a choice of projects that focussed on either the biophysics of DNA complexation in the chromosome or the biophysical characterization of hemocyanin, the giant copper-based oxygen binding protein of sea creatures such as mollusc and squid (see Kato et al. 2018a, 2018b in this issue). Fumio chose the latter because it would give him the opportunity to master the analytical ultracentrifuge, which both at that time, and continuing up to the present day, was/is the most powerful procedure for examining tertiary to quaternary transitions of macromolecules in solution. At that time, van Holde's laboratory at Oregon State University had a couple of model E analytical ultracentrifuges and van Holde was a true master of the technique with several key aspects of the methodology still bearing his stamp (van Holde and Weischet 1978; van Holde 1985).

The 3 years of Fumio's Ph.D. in Oregon were a formative period in his life for a number of reasons. From the science perspective, Fumio carried out fundamental work characterizing the linked allosteric and quaternary transitive behaviour of hemocyanin (Arisaka 1977; Miller et al. 1977; van Holde et al. 1977; Arisaka et al. 1979). Using the newly developed theoretical tools of thermodynamic linkage functions (Wyman 1964; Schellman 1975), Fumio developed, and experimentally tested, models relating the oxygen loading state and divalent cation concentration with the displacement of the hemocyanin monomer tetramer equilibrium (Fig. 4). Although a gamut of experimental methods were used, the analytical ultra-centrifugation (AUC) technique (both equilibrium and velocity methods) was the chief technique exploited to provide the experimental foundations for these studies (Arisaka 1977; Arisaka et al. 1979).

From the personal perspective, Fumio's time in America was also influential as it was here that he met the person who would later become his future wife. Another Japanese postdoctoral fellow at Oregon State University, (the then) Dr. Iho Yoshiyasu, introduced Fumio to a young Japanese traveller, Miss Hiroko Kawamori, who was coming to America as a tourist friend of Tho's wife Misuzu. In 1975, the four young Japanese went on a 2-week driving sightseeing tour in Fumio's old Pontiac station wagon, taking in the scenery of Utah, Arizona and California. Following this trip and Hiroko's return to Japan, the two engaged in increasingly friendly correspondence until eventually deciding upon marriage at the conclusion of Fumio's $\mathrm{PhD}$ and return to Japan.

The third perspective which would prove formative in Fumio's future life was the harsh reality of the tenuous employment situation and scant funding in science. At the end of his 1 year of JSPS funding, Fumio applied for, and received, a second year of funding from the Yoshida foundation. For his third year, Fumio received a Research Assistant position in the van Holde laboratory for which he had the duty of teaching a laboratory course. In total, the monies from JSPS, Yoshida Foundation and the Oregon State University were sufficient to keep him afloat until he successfully defended his dissertation in an open hearing in June of 1977. During these latter periods of his PhD, Fumio started to look for a position back in Japan that would enable him to marry and live with his future bride in waiting Hiroko. When such a position did not eventuate, he took the advice of a German postdoctoral fellow in the laboratory, Dr. Wolfgang Weischet, and looked further afield in Europe. This eventuated in the offer of a postdoctoral position with Prof. Jürgen Engel at the Biozentrum in Basel Switzerland.

Upon finishing $\mathrm{PhD}$ studies, Fumio made a lightning trip back to Japan, married Hiroko and submitted visa applications for the two of them to live and work in Switzerland. After conquering the inevitable visa problems that seem to afflict most scientists and their spouses at some stage of their lives, Fumio and Hiroko moved to Switzerland, to live and begin work at the Biozentrum.

\section{Academic career ladder}

Postdoctoral training in Switzerland (1977-1980) Now located in Basel, the newly minted Dr. Arisaka began work at the Biozentrum on what would prove to be his career defining research topic - the structural biology of T4 phage. However, but for a kind word from a colleague, this research path very nearly did not happen. At the Biozentrum, Fumio's new supervisor was Prof. Jürgen Engel, a giant in the field of collagen and actin polymerization (Wegner and Engel 1975; Engel et al. 1977). Knowing about Fumio's earlier work on actin filament assembly conducted with Profs. Maruyama and Noda, Engel offered Fumio a project concerned with the characterization of actin polymerization kinetics. Aware that young scientists need to develop by working on different topics, Engel also offered Fumio the chance to start on a new topic in the laboratory associated with bacteriophage. Taking a few days to think about it, Fumio received what would later prove to be sage advice from (a then) postdoctoral fellow in the neighbouring lab, Dr. Roel van Driel. Responding to Fumio's hesitancy that he had no background in microbiology, van Driel's advice was that,

(i) It is very healthy to change fields particularly early on in one's career.

(ii) Sometimes learning on the job provides a more focused introduction to a subject area than a more formal undergraduate preparation.

After some initial exploration with phage ${ }^{11}$, Fumio's confidence was raised sufficiently to begin a research project on the assembly mechanism of the T4 phage tail sheath protein (gp18) onto the phage tube baseplate (Arisaka et al. 1979; Tschopp et al. 1979; Arisaka et al. 1980; Arisaka et al. 1981). For Fumio, the microbiology aspect of this work turned out to be surprisingly easy, the T4 phage tail sheath protein was prepared by inoculating

\footnotetext{
${ }^{11}$ In which Fumio was amazed that a small drop of bacteriophage could kill all cultured E. coli cells in just $20 \mathrm{~min}$.
} 

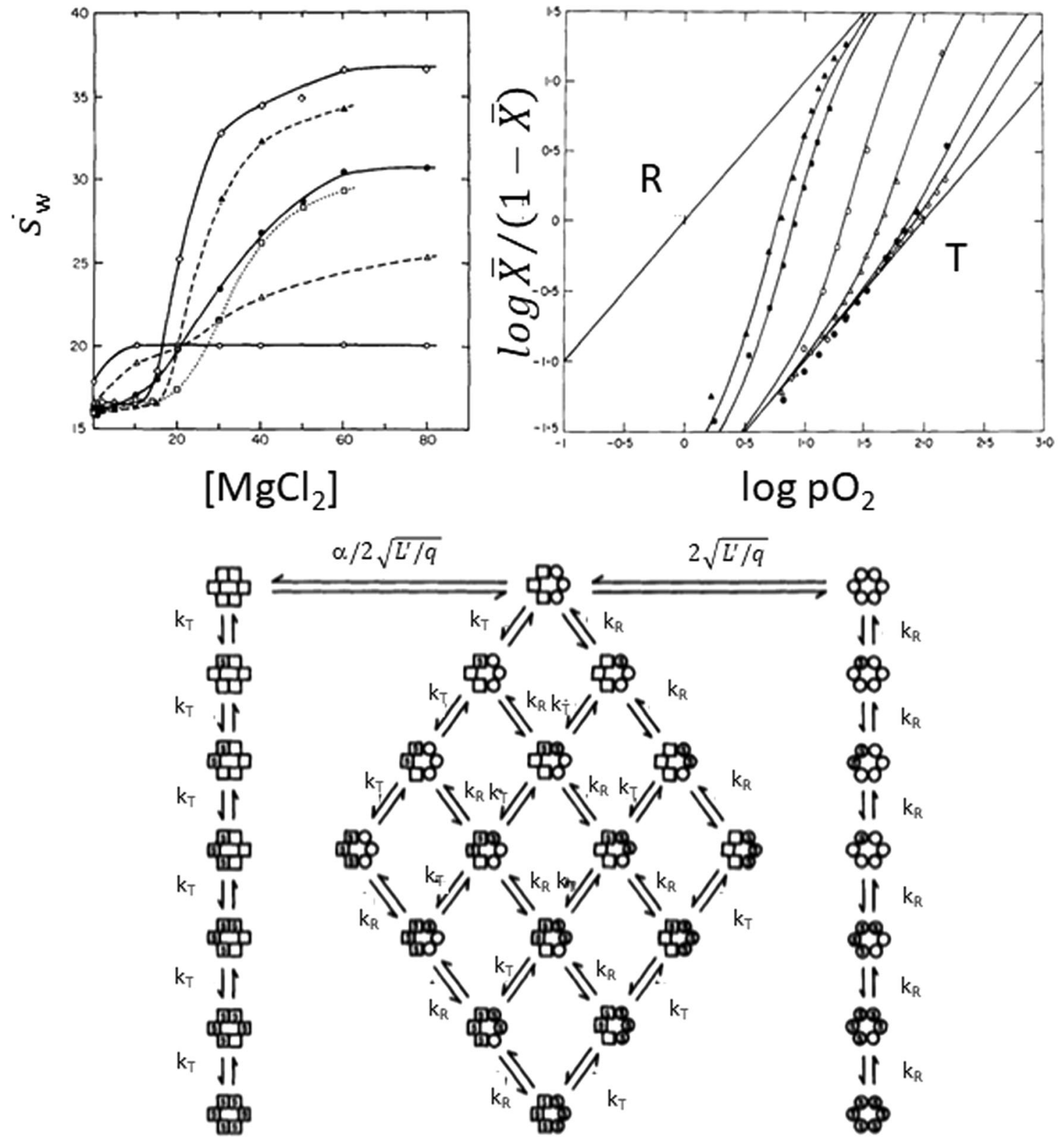

$$
\begin{aligned}
K= & K_{0}\left\{\frac{1+L_{\mathrm{M}}^{\prime}+2 \sqrt{ }\left(L_{\mathrm{M}}^{\prime} / q\right)}{1+L_{\mathrm{Te}}^{\prime}+2 \sqrt{ }\left(L_{\mathrm{Te}}^{\prime} / q\right)}\right. \\
& \left.\cdot \frac{(1+\alpha)^{6}+L_{\mathrm{Te}}^{\prime}(1+c \alpha)^{6}+2 \sqrt{ }\left(L_{\mathrm{Te}}^{\prime} / q\right)(1+\alpha)^{3}(1+c \alpha)^{3}}{(1+\alpha)^{6}+L_{\mathrm{M}}^{\prime}(1+c \alpha)^{6}+2 \sqrt{ }\left(L_{\mathrm{M}}^{\prime} / q\right)(1+\alpha)^{3}(1+c \alpha)^{3}}\right\} \frac{\left(1+k_{\mathrm{\gamma}} y\right)^{4 p}}{\left(1+k_{\mathrm{z}} z\right)^{8 p}},
\end{aligned}
$$

an E. coli culture with T4 head-deficient mutant phage, followed by a sucrose gradient density centrifugation step and a final dialysis against water - conditions under which the sheath protein dissociates. Using this material as his starting product and utilizing the familiar tools of sedimentation velocity and transmission electron microscopy, Fumio showed that the assembly of the $72 \mathrm{~S}$ tube-baseplate with the $5 \mathrm{~S}$ tail sheath protein was a highly cooperative process that could be facilitated by moderate concentrations of potassium chloride (Arisaka et al. 1979; Arisaka et al. 1980). Through the development of analytical cooperativity models (Fig. 5), Fumio and colleagues demonstrated that the degree of cooperativity for binding of gp 18 to tail sheath was directly 
4 Fig. 4 Fumio's Ph.D. thesis title at Oregon State University was 'Allosteric Properties and the Association Equilibria of Hemocyanin from Calianassa Californiensis'. The following demonstrate some of the experimental and theoretical approaches adopted by him during that time. (Top left) Weight average sedimentation coefficients of hemocyanin as a function of $\mathrm{Mg}^{2+}$ concentration at different $\mathrm{pH}$ conditions (hemocyanin concentration $1 \mathrm{mg} / \mathrm{ml}$, temperature, $20{ }^{\circ} \mathrm{C}$. (open diamonds) $\mathrm{pH} 8.2$; (filled triangles) $\mathrm{pH} 7.65$; (closed circles) $\mathrm{pH} 7.0$; (open squares) $\mathrm{pH} 7.3$; (open triangles) $\mathrm{pH} 6.5$; (open circles) $\mathrm{pH}=$ 6.0). (Top right) Hill cooperativity plots of the binding of $\mathrm{O}_{2}$ by hemocyanin $\mathrm{C}$ at $25{ }^{\circ} \mathrm{C}$ (as determined by spectral shift changes in a cell equipped with a tonometer). Two straight lines with slope unity ( $\mathrm{T}$ and $\mathrm{R}$ ) represent behaviour of hypothetical non-transitive tense and relaxed states. The $\mathrm{pH}$ and $\mathrm{MgCl}_{2}$ concentrations were as follows: (filled triangles) 8.2, $60 \mathrm{mM}$; (filled squares) 8.2, $26 \mathrm{mM}$; (open circles) 7.9, $20 \mathrm{mM}$; (open triangle) 7.6, $26 \mathrm{mM}$; (closed circle) 7.4, $26 \mathrm{mM}$; (open diamond) 7.4, $0 \mathrm{mM}$. (Centre) One of the sub-cases considered: linked binding and allostery scheme for structural change accompanying divalent cation ion and molecular oxygen binding to the hemocyanin 'monomer' (composed of six protein chains). (Bottom) Another considered subcase: analytical function describing the linkage between divalent cation, hydrogen ion and oxygen binding and an observable 'monomer to tetramer' quaternary transition of hemocyanin. Figures reproduced with permission from Arisaka and van Holde, 1979

determined by the salt concentration - a paradigm that closely mirrored the situation for actin polymerization (Straub 1943).

Although he very much enjoyed working with Engel, both Fumio and Hiroko desired to return to Japan and continue to grow their family. ${ }^{12}$ With two overseas stints (one for his $\mathrm{PhD}$ and one for his first postdoc), Fumio now started the hunt for a job back in Japan. As luck would have it at that time, the Biozentrum was hosting a talk by Prof. Shin-Ichi Ishii, an expert on the protein chemistry of proteases and lectins, who was affiliated with the Department of Pharmacy at Hokkaido University. Down with influenza, the Biozentrum host asked Fumio if he would chaperone the Japanese guest speaker during his stay. After getting to know both Fumio and of his desire to return home, Prof. Ishii promised to keep his ears open for a position. The two parted on friendly terms with Fumio thinking that Prof. Ishii might be a useful source of introduction to make his way back to Japan.

\section{An Assistant Professorship in Hokkaido (1980-1990) Nine} months after Fumio said goodbye to Prof. Ishii in Basel, he received an offer of an Assistant Professor position - from no one other Prof. Ishii himself. Keenly interested in the work Fumio was doing with Engel on phage, Ishii encouraged Fumio to continue on that topic at Hokkaido University located in Sapporo. ${ }^{13}$ However, this opportunity was to be rather heavily balanced against the daily realities of an Assistant Professor position in Japan. ${ }^{14}$ Aside from tending to the day-to-day requirements of

\footnotetext{
12 For now, there were three Arisaka's with Fumio and Hiroko's first son Michio being born in Switzerland.

${ }^{13}$ Prof. Ishii's interest in phage was spurred by his discovery that the R-type pyocins of Pseudomonas Aureginosa bore close resemblance to the T4 phage tail.

${ }^{14}$ Of which all three of this Editorial's authors can attest. The title of Assistant Professor in Japanese is jokyo.
}

the Professor's laboratory, Fumio was also required to both extensively demonstrate and supervise lab practicums. Despite this heavy teaching load, Fumio still found time to achieve two important things,

(i) He produced a series of high-quality research papers related to phage biology (Nakagawa et al. 1985; Kumazaki et al. 1986; Maruyama et al. 1986; Arisaka et al. 1987; Arisaka et al. 1988a, 1988b).

(ii) Increased his family size (with another three sons ${ }^{15}$ born during his time in Sapporo).

During this time one scientific finding of particular note was his discovery that gene product 5 of the T4 phage genome possessed lysozyme activity and was located in the phage tail baseplate (Fig. 6) (Nakagawa et al. 1985). This work was a key discovery in the field as a protein possessing lysozyme like activity was previously postulated to be essential for local digestion of the bacterial peptidoglycan layer (Kao and McClain 1980), thereby allowing the phage tube to penetrate into the E. coli periplasmic space and deliver its viral DNA. During this time, Fumio also collected a sizeable number of gene 5 and gene 18 mutants exhibiting various phenotypes and started to sequence their genome to identify the mutation sites.

Enjoying both his young family's quiet life in Japan's northern island of Hokkaido and the pleasant work situation (eventually settling into a suitable balance of research and teaching), Fumio admits to a certain contentedness during his 10-year stay in Prof. Ishii's lab. However, in the cutthroat world of academia, in which stagnation can lead to career death, it was time to make the next career jump to Associate Professor. After receiving a number of rejections on his eighth application, he achieved success, securing a position at the prestigious Tokyo Institute of Technology. After relocating his family from Hokkaido to Yokohama, the then Assist. Prof. Arisaka took on an Associate Professor position in the laboratory of Prof. Tairo Oshima.

Associate professor at the Tokyo Institute of Technology (1990-2010) In the late 1980s, Prof. Tairo Oshima was a famous figure on the Japanese science scene. Working on the origin of life topic, Prof. Oshima had spent time at NASA investigating underwater volcanic vent deep sea life. After returning to Japan, he discovered Thermus Thermophilus, a hyperthermophile now studied and exploited all over the world (Oshima and Imahori 1974). Starting in 1990, Fumio's appointment was decided partly on the basis of his teaching potential and partly on his future capacity for research into phage biology. With a prestigious position and a

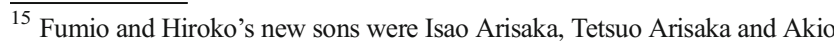
Arisaka.
} 

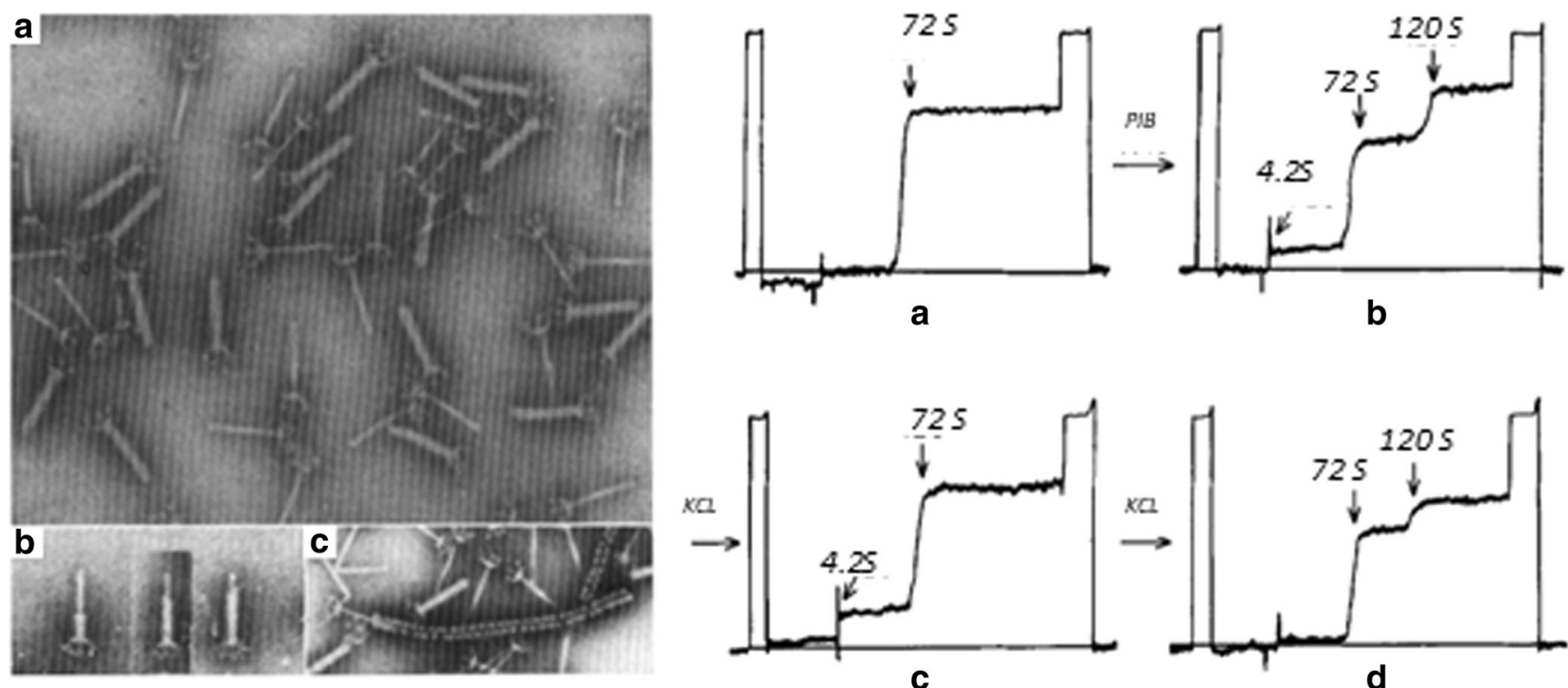

a

b

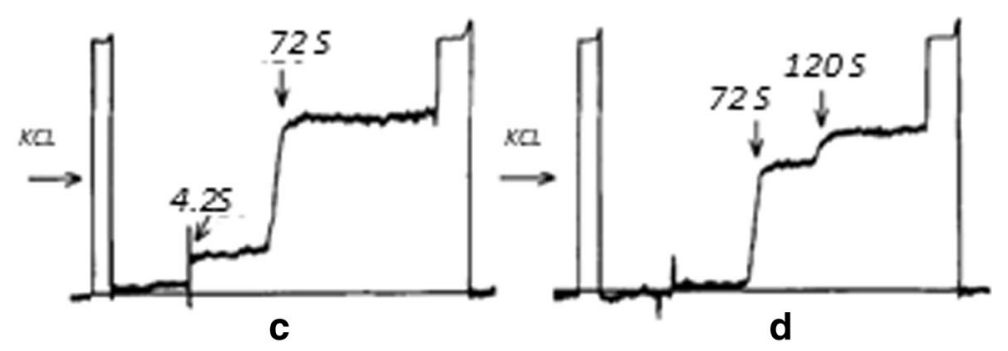

$\mathrm{B}+\mathrm{A} \stackrel{o K}{\rightleftarrows} \mathrm{BA}$

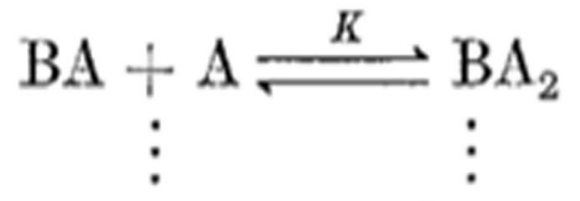

$\mathrm{BA}_{n-2}+\mathrm{A} \stackrel{K}{\longleftarrow} \mathrm{BA}_{n-1}$
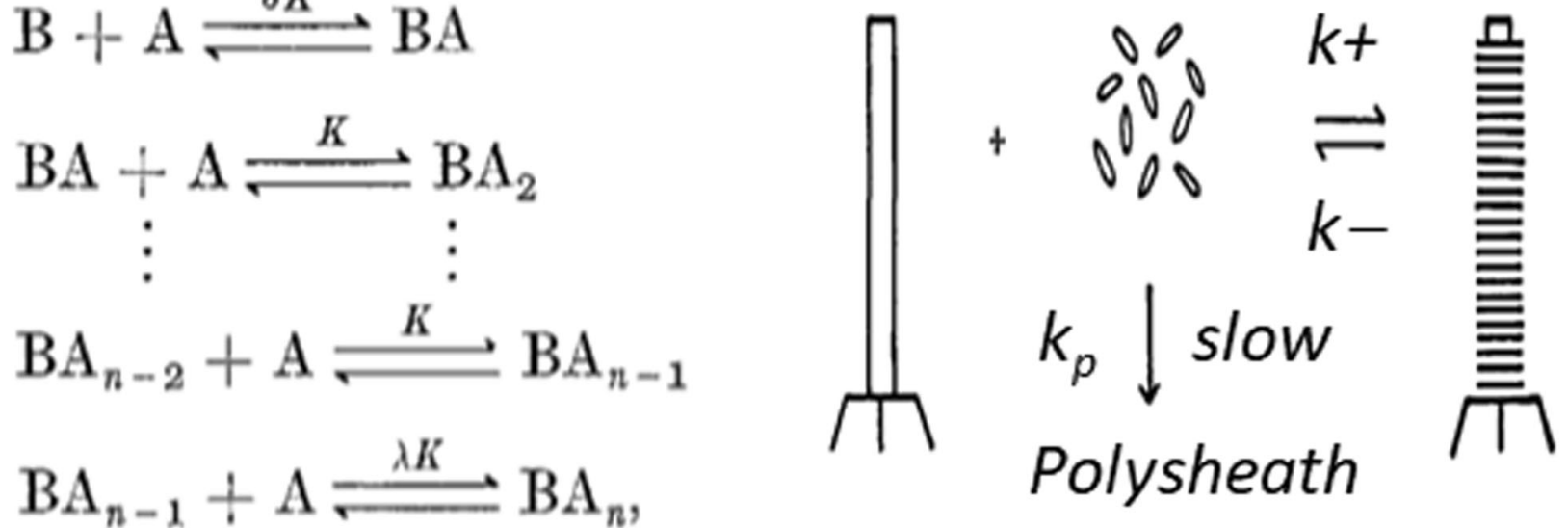

Fig. 5 The start of Fumio's research on the T4 bacteriophage at the Biozentrum in Basel Switzerland. (Top left) Electron micrograph of reassembled T4 tails showing the 'all or nothing' cooperativity effect promoted by $0.1 \mathrm{M} \mathrm{KCl}$ in the process of binding of the $144 \mathrm{gp} 18$ tail sheath proteins to the phage baseplate (see Fig. 1 of Arisaka et al. 1979 for more details). (Top right) Sedimentation velocity analysis of the effect of $0.1 \mathrm{M} \mathrm{KCl}$ on the cooperative mixing of standard solution mixtures of gp18 and core-baseplate. The 4.2, 72 and $120 \mathrm{~S}$ boundaries represent

happy and healthy young family, things indeed looked very bright for Fumio.

However, in both life and research, problems can (and frequently do) arise, and it is often during the process of facing and overcoming these difficulties that we are able to measure the depth of our character. For Fumio, such unexpected challenges arose from left-field and were tripartite in nature. The first involved a sudden strict tightening of Japan's research budget due to the collapse of the Tokyo property bubble, the timing of which was coincident with his starting at the Tokyo Institute of Technology. The squeeze on government research grants that accompanied a halving of the value of Japanese Stock market

monomeric gp18, core-baseplates and completely sheathed tails, respectively. (Bottom left) A kinetic and thermodynamic model developed by Fumio to describe the cooperative behaviour of the binding of gp1 8 to the core-baseplate (where $\lambda>1>\sigma$ ). (Bottom right) Schematic model developed by Fumio to describe both the cooperative binding of gp18 to the core baseplate as well as the competitive aberrant formation of the 'polysheath' structure seen in the images in the top left of this figure (figures reproduced with permission from Arisaka et al. 1979)

and a near collapse of the banking industry in 1991 was felt by academics throughout Japan but this was especially so for a just starting out Associate Professor. The second challenge was the retirement of Prof. Oshima which occurred five years after Fumio's commencement. To maintain continuity of research theme, the normal reaction within Japanese research institutes to such a retirement is to promote the subordinate Associate Professor paired to the retiring Professor and rehire a new Associate Professor as the newly appointed Professor's subordinate. However, due to continued difficulties with finances, as a cost saving measure, Fumio's institute decided to replace the retiring Professor with another tenured Associate Professor and 

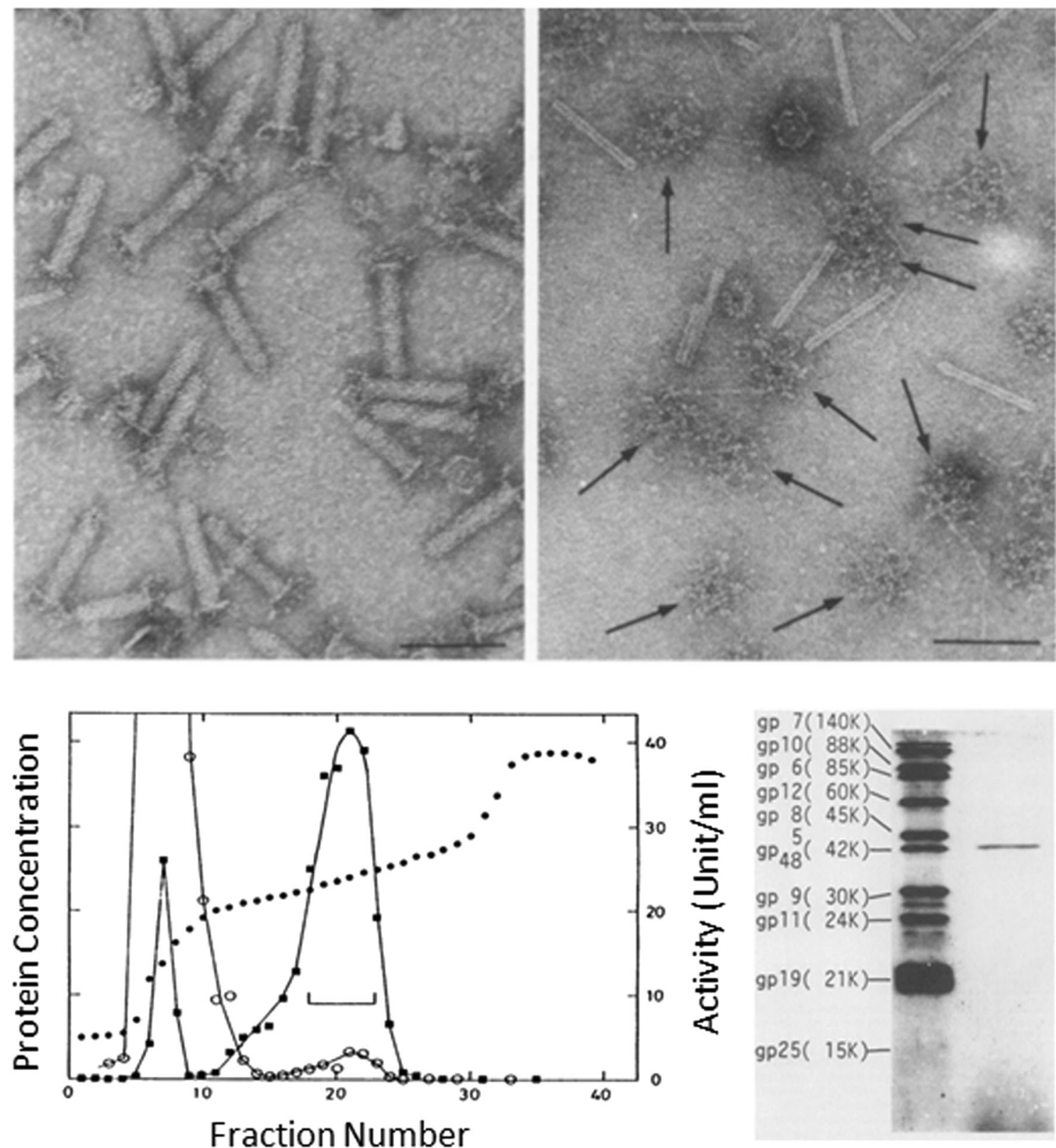

Fig. 6 A major discovery made during Fumio's Assistant Professorship at Hokkaido University. Fumio and coworkers provided direct evidence proving that the tail-associated lysozyme of bacteriophage T4 (taillysozyme) was gp5 and that gp5 was a component of the baseplate hub. (Top left and right) Electron micrographs of T4 phage tails before (left) and after (right) treatment with $3 \mathrm{M}$ guanidine hydrochloride containing $1 \%$ Triton X-100 (which dissociates the baseplate from the sheath spoke and sheath proteins). Arrows indicate baseplates in star form. Bars, $100 \mathrm{~nm}$. (Bottom left) Preparative isoelectric focusing chromatography of T4 phage tail proteins after initial treatment with partially denaturing

have the two compete against each other over a 5 -year period for the vacant professorial post. Needless to say, such circumstances were tough and not optimal for fostering friendship and collegiality! The third major challenge of Fumio's early tenured period involved the changing nature of biochemical science. Those readers old enough to remember will recall that the late 1980s and early 1990s saw the decline of traditional biochemistry and solution (3 M guanidine hydrochloride containing $1 \%$ Triton X-100) followed by dialysis against $1 \mathrm{mM}$ phosphate buffer, $\mathrm{pH}$ 7.2, containing $1 \%$ Triton $\mathrm{X}-100$. The dialyzed solution was then loaded on a preparative isoelectric focusing column. Lysozyme activity (filled squares) and protein concentration (open circles) were localized to fraction number 21 . (Bottom right) SDS gel electrophoresis of tail-lysozyme isolated by the isoelectric focussing chromatography step and the total protein isolate from the phage tube-baseplates (figures reproduced with permission from Nakagawa et al. 1985)

the rise of molecular biology. With the retirement of Prof. Oshima, the chief champion of Fumio's type of biophysical research approach into phage was lost within the Department, whose collective research focus was temporarily diverted by the many new available aspects of DNA technology. For the moment, the purification and physical characterization of reassembled phage components were suddenly considered old 
fashioned! However, with the characteristic steadiness of character that is admired by those who know him, Fumio applied himself to overcome these obstacles and slowly but surely his research program began to blossom.

In the early tough periods without significant funding, Fumio kept his academic career alive by writing up existing work on phage biology from Hokkaido University (Takeda et al. 1990; Arisaka et al. 1990), engaging in collaborative work with colleagues ${ }^{16}$ (Powell et al. 1990; Ikai et al. 1993; Kosukegawa et al. 1996; Kojima et al. 1996; Morii et al. 1997; Inamori et al. 1999; Hoque et al. 1999a, 1999b; Inoue et al. 2000; Inamori et al. 2001; Kawabata et al. 2000; Suzuki et al. 2001) and penning a series of influential single-author review papers for Japanese journals on various aspects of biophysical chemistry such as analytical ultracentrifugation, phage biology and the theory of protein-protein interactions (Arisaka 1992, 1994a,b, 1998a, b, c, 1999, 2001). ${ }^{17}$ As his own research program began to develop, Fumio started to produce a bevy of high-quality original research papers on his principal phage using a mixture of biophysical (Ikai et al. 1993; Matsui et al. 1997; Zhao et al. 2000) and genetic engineering methods for identifying amino acid sites of mutants with various phenotypes (Takeda et al. 1998a; Takeda et al. 1998b) (Fig. 7). These collective research efforts were accompanied by the writing of three very significant textbooks. Two of these 'Standard Seikagaku' (Standard Biochemistry) (Arisaka 1996) (later re-published as 'Yoku Wakaru Standard Seikagaku' (Easy to Understand Biochemistry) (Arisaka et al. 2016)) and 'Introduction to Protein Science' (Arisaka 2004) stemmed from Fumio's extensive original teaching notes. ${ }^{18}$ The third textbook 'Butsuri Seikagaku' was a commissioned translation from English to Japanese of Kensal Edward van Holde's classic 'Physical Biochemistry' ${ }^{19}$ (Van Holde 1985).

Of great help to Fumio during the make or break, Associate Professor period was the sequential recruitment of two talented Assistant Professors, Shigeki Takeda (1998-2000) and Shuji Kanamaru (2003-2014). Shigeki Takeda was previously a Masters student that Fumio had helped to train during his time

\footnotetext{
${ }^{16}$ In this regard, the acquisition of a new Beckman XLA analytical ultracentrifuge by Fumio and the Tokyo Institute of Technology made the institute the hub for ultracentrifugation experiments in Japan.

${ }^{17}$ Even at that time, the 'publish or perish' paradigm was the harsh reality of life for scientific researchers.

18 'Standard Seikagaku' has gone through three editions and numerous reprintings over the course of 21 years (1996-2015) with a fourth edition recently requested by the publisher which was published as a new textbook 'Yoku Wakaru Standard Seikagaku' in 2016. In addition to 'Standard Seikagaku', 'Introduction to Protein Science' and 'Butsuri Seikagaku', Fumio has written or coauthored a further four textbooks 'Tanpakushitsu no Jikoshuugou' (Protein Self-Association), 'Tanpakushitsu Kogakuno Kiso' (Protein Engineering Basics), 'Tanpakushitsu no Katachi to Bussei' (Protein Shape and Properties - written together with $\mathrm{HN}$, one of the three editors of this special issue) and an edited book on Analytical Ultracentrifugation written with two of the contributors to this special issue Susumu Uchiyama and Satoru Unzai.

${ }^{19}$ Kensal Edward van Holde was Fumio's PhD supervisor.
}

as an Assistant Professor in Hokkaido. During that time, they worked on a series of studies on the structure and function of the contractile tail sheath protein of bacteriophage T4 (Takeda et al. 1990; Arisaka et al. 1990). After a period completing his DSc and working as a postdoctoral fellow at the University of Tokyo, Shigeki Takeda received an offer from Fumio of the first Assistant Professor position in his laboratory. At this time, the newly appointed Assistant Professor Takeda helped Fumio to further establish his laboratory and recruit graduate students. Aside from this, Shigeki also made a number of key scientific findings, the most important of which was the discovery of the tail tube gene of Mu phage (Takeda et al. 1998b) - the model phage system particularly famous for its role in determining the action of transposable elements (also known as jumping genes) (Shapiro 1979). After completing his training with Fumio, Shigeki Takeda was later promoted to Associate Professor at Gunma University - the same university where he is now a full Professor, running his own laboratory on the topic of phage biology (Takeda 2018).

One of the Tokyo Institute of Technology graduate students recruited and trained by Fumio and Shigeki was Shuji Kanamaru - and it was he who would later go on to play a major role in making the quantum jump in the phage structural biology studied in the Arisaka laboratory, from the mesoscopic, to the atomic level of resolution. Graduating from his DSc course in 1999 (Kanamaru et al. 1999), the then brand new Dr. Shuji Kanamaru was encouraged by Fumio to go to America to engage in postdoctoral studies in the laboratory of his new collaborator, Prof. Michael Rossmann (Rossmann 2018) (Purdue University, Indiana). Fumio and Michael had previously discussed the possibility of jointly supervising a project aimed at determining the atomic structure of the $\mathrm{T} 4$ phage components by X-ray crystallographic analysis. Working together with a number of Rossman's talented Ph.D. students and postdoctoral fellows (among them Petr Leiman and Victor Kostyuchenko, who originally came from Vadim Mesyanzhinov's laboratory - another of Fumio's collaborators), Dr. Shuji Kanamaru determined the first high-resolution crystal structure of the (gp5gp27) $)_{3}$ complex and fit this complex into a cryo-EM image of the complete T4 phage baseplate (Kanamaru et al. 2002) (Fig. 8). Production of an atomic resolution description of the cell puncturing device provided, for the first time, the essential information to manipulate the phage machinery for bionanotechnology imperatives (Rossmann et al. 2004; Inaba and Ueno 2018). ${ }^{20}$

\footnotetext{
${ }^{20}$ Collaborative work performed between the Rossmann and Arisaka laboratories has continued right up until the present day. With over thirteen jointly co-authored papers this connection is regarded by Fumio as one of the key positive engagements of his working life. In private conversation Fumio has remarked that the selection of a good collaborator has as much to do with temperament and character as scientific excellence and that in Michael Rossmann he found a wellspring of both.
} 

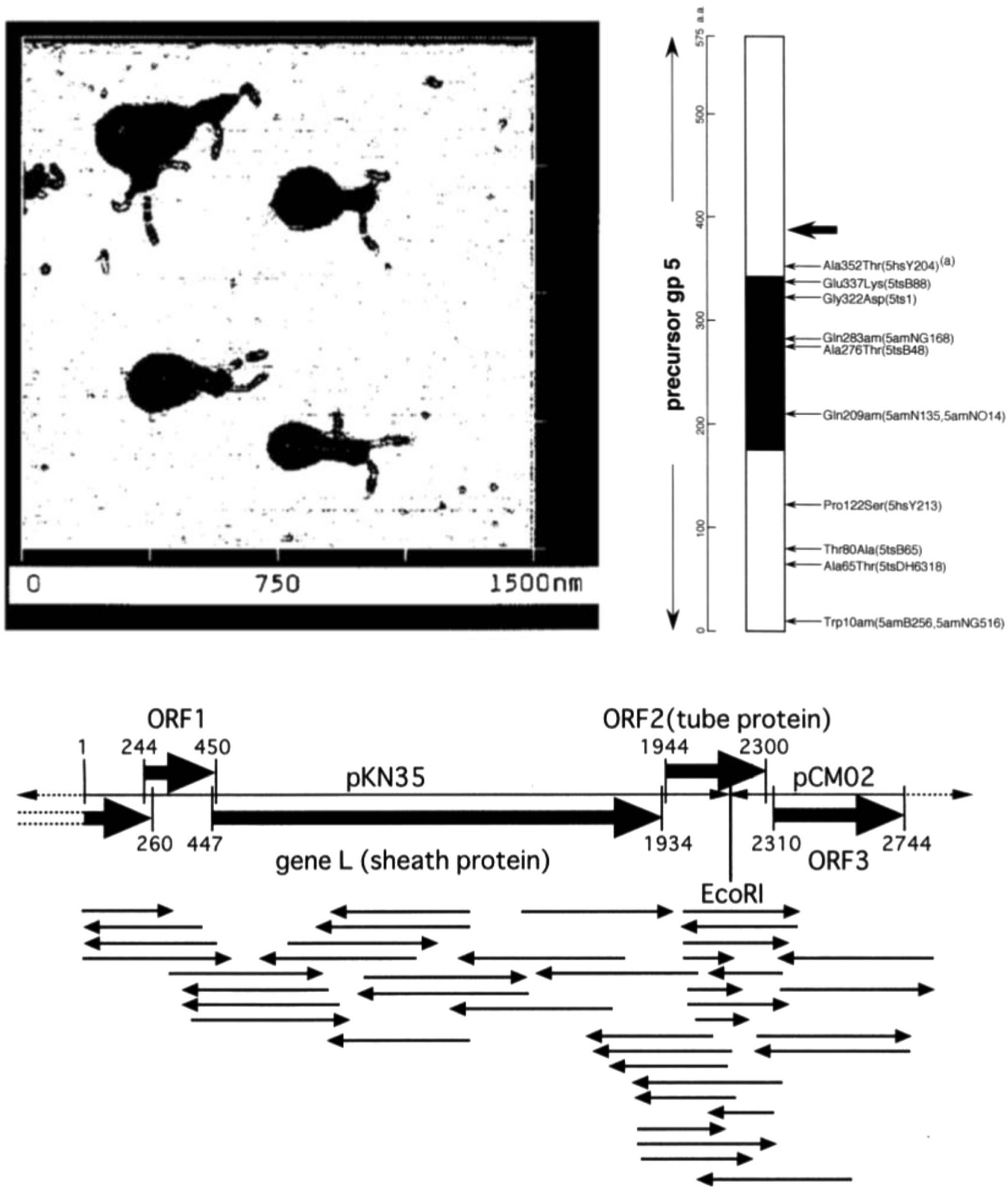

Fig. 7 Early progress in phage biophysical research made during the initial stage of Fumio's Associate Professorship at the Tokyo Institute of Technology. (Top left) The second ever visualization of T4 phage using the technique of atomic force microscopy (reproduced with permission from Ikai et al. 1993). (Top right) Mapping and identification of a set of gene 5 point mutants that determined a series of 'toolbox' phenotypes used by phage researchers over the previous 50 years (reproduced with permission from Takeda et al. 1998a). (Bottom) Sequencing of the phage genome - strategy and the determined gene organizationn flanking the $\mathrm{Mu} \mathrm{L}$ gene where arrows represent the direction of sequence and the size of the sequenced fragment (reproduced with permission from Takeda et al. 1998b) 
a

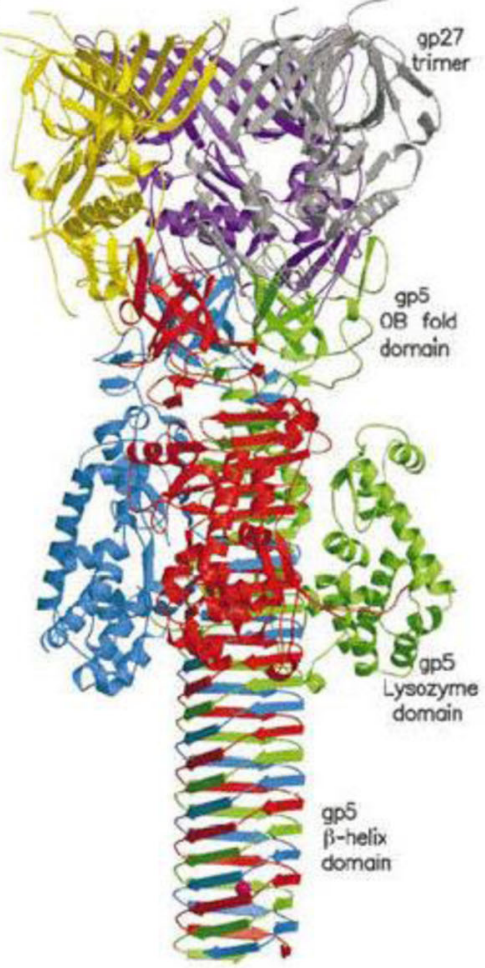

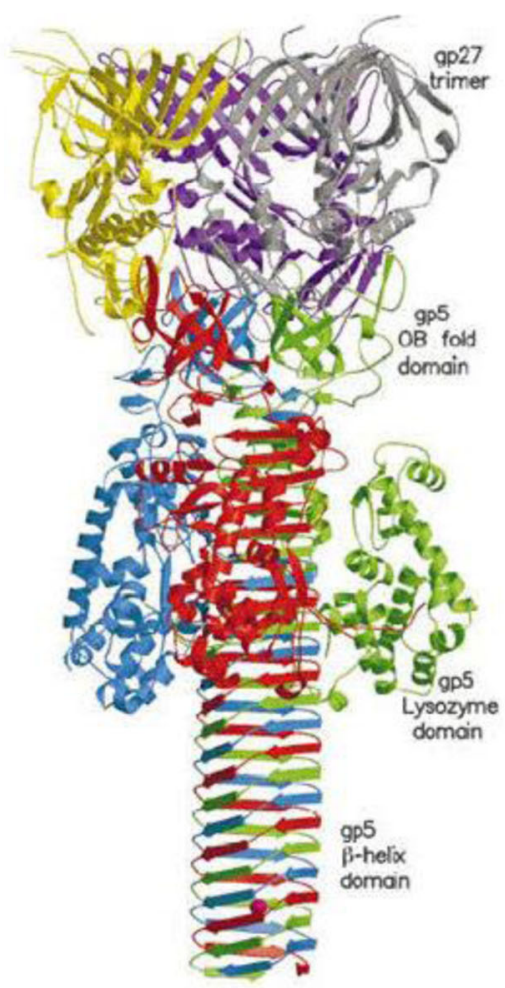

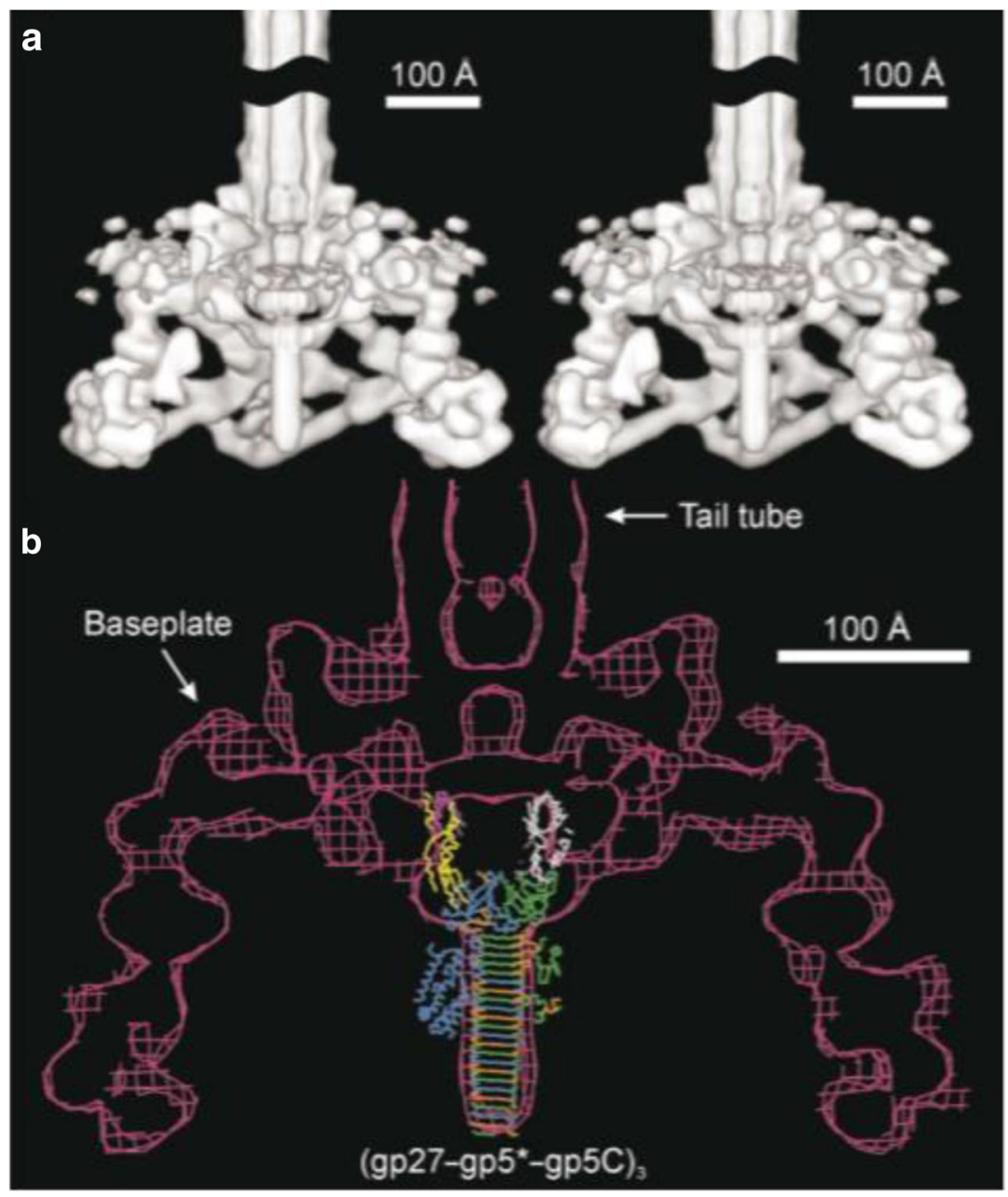


4 Fig. 8 Structural biology of T4 phage becomes a reality with highresolution X-ray crystal of the needle puncture apparatus (the (gp27gp $5{ }^{*}$-gp5C) $)_{3}$ complex) and cryo-EM structures of the decorated sheath and baseplate units. (Top) Stereo diagram representation of the X-ray crystal structure of the $(\mathrm{gp} 27 \text {-gp } 5 * \text {-gp5C) })_{3}$ complex. The three gp5 monomers are coloured red, green and blue. The three gp27 monomers are coloured yellow, grey and purple. (Bottom) A stereo view of the cryoEM reconstruction of the T4 baseplate-tail tube assembly with the highresolution crystal structure of the (gp27-gp $5 *$-gp5C $)_{3}$ cell puncturing device fitted into the relevant cryo-electron microscopy density. Both figures reproduced with permission from Kanamaru et al. 2002

With a recent Nature publication (Kanamaru et al. 2002) and the appointment of a new Assistant Professor (Shuji Kanamaru returned from the US), Fumio's research program began to gather pace and riding high on the success of the high profile Nature publication from that time onwards he received a series of requests for invited review articles (Kanamaru and Arisaka 2002; Arisaka et al. 2003; Leiman et al. 2003; Rossmann et al. 2004; Kanamaru and Arisaka 2005; Arisaka 2005) and an increased demand for collaborative engagements (Suzuki et al. 2002; Miller et al. 2003; Okabe et al. 2003; Myszka et al. 2003).

It was during this time that Fumio started what would prove to be another very successful engagement, this time with Dr. Peter Schuck of the NIH. Introduced to Peter by Dr. Allen Minton (also of the NIH and Peter's first postdoctoral supervisor) (Rivas and Minton 2018), the two of them found that they had a jointly shared interest in the AUC technique. At that time, Peter had developed a novel way of analyzing sedimentation velocity profiles that was dependent upon rapid numerical solution of the sedimentation transport equations (Schuck 2000). Looking for international users of his 'Sedfit' approach, Fumio was the obvious choice to introduce the method to a Japanese audience. This collaboration resulted in one of the very first experimental uses of what has now become the standard method of analysis in the field (Ali et al. 2001) (Fig. 9). This publication also further cemented Fumio as the key user of the technique in Japan - a role that he has very actively further built upon by mentoring junior colleagues who have also become principal users of AUC technique (Unzai 2018; Uchiyama et al. 2018) and personally engaging in numerous collaborations since that time (Abe et al. 2004; Takahashi et al. 2004; Shimizu et al. 2005; Urano et al. 2006; Sugimoto et al. 2006; Morimoto et al. 2006; Ueno et al. 2006; Hara et al. 2006; Arakawa et al. 2007; Abe et al. 2007; Sano et al. 2007; Makino et al. 2007 et al. 200; Matsuda et al. 2007; Absar et al. 2008; Koshiyama et al. 2008; Kita et al. 2008; Mio et al. 2008; Absar et al. 2008; Tokunaga et al. 2008; Arakawa et al. 2008; Arisaka et al. 2008; Watanabe et al. 2008; Saidaie et al. 2008; Arisaka et al. 2009; Roberts et al. 2009; Koshiyama et al. 2009; Arakawa et al. 2009a, 2009b).
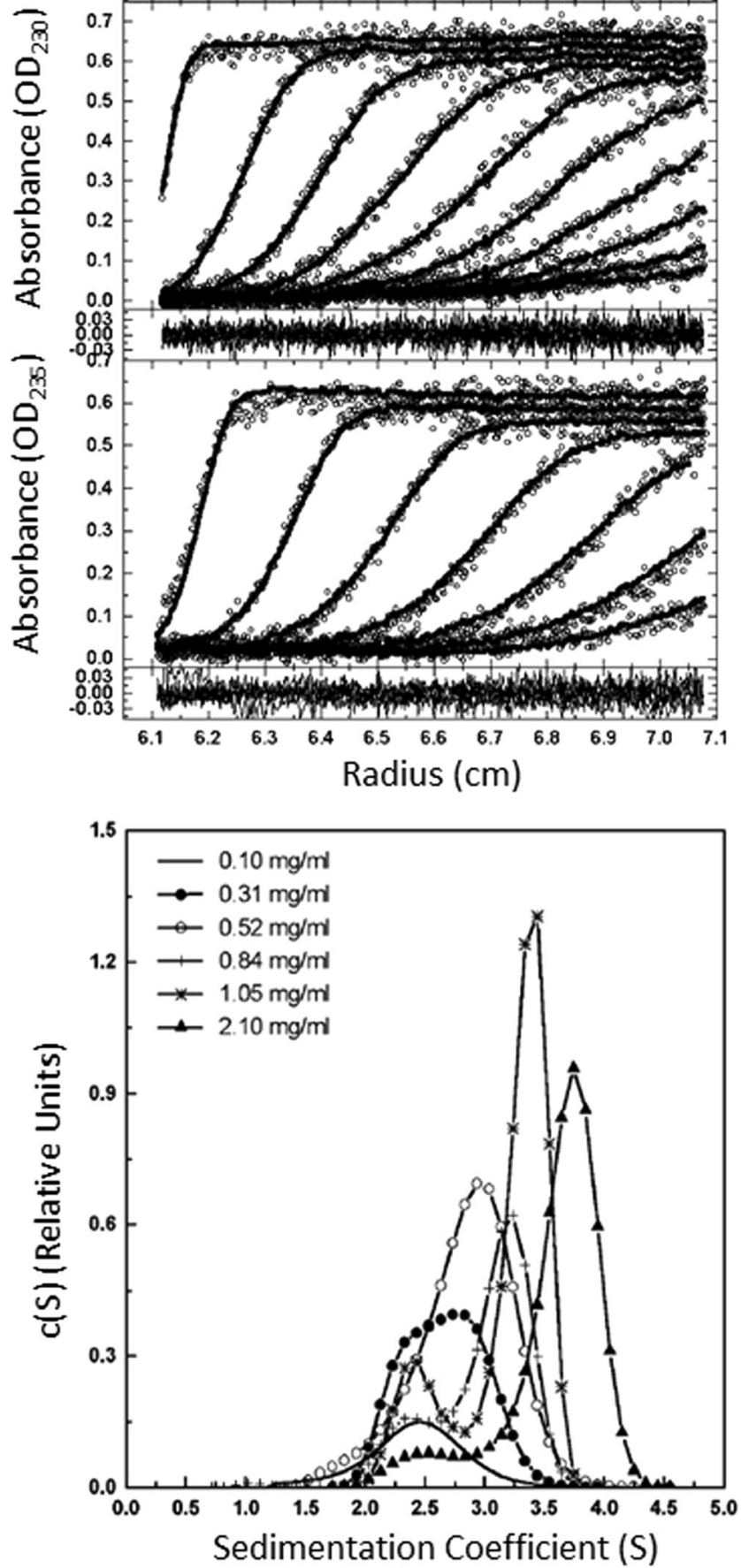

Fig. 9 Fumio has always been at the forefront of analytical ultracentrifugation methodology. This example describes one of the first applications by Japanese researchers of numerical based fitting of the complete sedimentation profile - a technique that has come to be known as the c(s) distribution analysis implemented in the Sedfit software. The method was used to determine the association behaviour of the gp57A molecular chaperone of bacteriophage T4. (Top) Analysis of raw sedimentation velocity data according to an explicit trimerhexamer-dodecamer model (obtained at 50,000 rpm at $20{ }^{\circ} \mathrm{C}, \mathrm{pH} 8.0$ at concentrations of 0.52 and $2.1 \mathrm{mg} / \mathrm{ml}$ ). (Bottom) T4 phage gp57A sedimentation coefficient distribution $\mathrm{c}(\mathrm{s})$ as a function of loading concentration of the gp57A protein. Figure reproduced with permission from Ali et al. (2001) 
Following on from the high profile structure paper, Shuji and Fumio, together in collaboration with the Rossmann and Takeda laboratories, continued to advance both the structural (Kostyuchenko et al. 2005; Rossmann et al. 2007; Akhter et al. 2007; Kanamaru and Arisaka 2007; Nemoto et al. 2008) and functional (Zhao et al. 2003; Takeda et al. 2004; Kanamaru et al. 2005; Kumar-Sarkar et al. 2006; Koshiyama et al. 2009) understanding of phage biology to such an extent that the phage structural components began being seriously discussed in terms of bionanomachinery (Rossmann et al. 2007). During this time, a number of excellent D.Sc. students including Takuro Matsui, Said Ali, Lily Zhao, Tahmina Akther, Mai Nemoto, Moh Lan Yap, Takafumi Iura and Kazuya Uchida along with many Masters students were, together with Shuji Kanamaru, the driving force behind the discoveries made in Fumio's laboratory. Two more important events happened during this time - the first being the recruitment of Ms. Moh Lan Yap, an exceptionally talented DSc student from Malaysia (who would later lead the next charge of phage structural biology from Fumio's laboratory) and the second being Fumio's promotion to full Professor.

\section{Professor at the Tokyo Institute of Technology (2010-2015) In} the late 2000s, phage biology enjoyed a resurgence in popularity - a situation mostly due to the structural biology efforts championed by Fumio Arisaka and Michael Rossmann in the late 1990s and early 2000s. This newfound appreciation of the research area, together with a loosening of the funding spigots that always accompanies the publication of high profile/high impact papers, meant that Fumio's research was now (once again) considered important and this re-evaluation catalyzed his promotion to a full Professorship in the Department of Life Science at the Tokyo Institute of Technology. Although providing a number of advantages, the promotion did not affect Fumio as much as it might have a much younger scientist. Fumio was already the leader of his field in Japan and one of the elite researchers in phage biology worldwide (as evidenced by a number of contributions to this special issue from office holders of the International Society for Phage Biology (Quax and Daum 2018; Hyman and van Raaij 2018; Dowah and Clokie 2018; Serwer et al. 2018)). Similarly, he was at the top of the tree with regard to expertise in biophysical characterization as could be easily shown by the long line of researchers within Japan wanting to collaborate with him.

However, the extra space and research funding associated with a full Professorship allowed Fumio to take on more students one of whom, Moh Lan Yap, he set the ambitious task of investigating the mechanism of assembly of the T4 phage base plate apparatus (Yap et al. 2010a, b). Beginning with the expression of a very large number of recombinant $\mathrm{T} 4$ phage baseplate wedge proteins, this work employed a combinatorial mixing approach complemented by analysis using sedimentation velocity methods to determine the stoichiometry and mechanistic order of phage baseplate assembly (Yap et al. 2010a, b). Such a discovery was profound in the sense that it proved that successful assembly of complex bio-nanomachines is rule dependent and not achievable by simple mixing of the components (Fig. 10). This work was followed up with a summarizing account in what is still considered as the defining review article on the structural biology of phage (Leiman et al. 2010). Upon graduating from her DSc course, Dr. Moh Lan Yap (with Fumio's encouragement) followed Shuji Kanamaru's path to a postdoctoral position in the laboratory of Prof. Michael Rossman. As the focal point of collaboration between these two laboratories, Moh Lan's investigations solved another unknown problem associated with the structural conversion of the compact and expanded states of the membrane anchoring T4 phage baseplate (Yap et al. 2014; Yap et al. 2016; Arisaka et al. 2016). This work highlights an important aspect of bio-nanomachine function that relates to how motion within nano-to-micro meter sized structures determines their ability to do useful work (Rossmann et al. 2007; Arisaka et al. 2016).

During this latter period, other students and postdoctoral fellows associated with Fumio's research area made significant discoveries in their particular projects. Within the phage-related area work on bacterial homologs of phage proteins (Uchida et al. 2014), mechanistic action of the gp5 trimer in the cell puncturing device (Nishima et al. 2011), and determination of the molecular architecture of the T4 phage neck region (Fokine et al. 2013) (all reviewed in Arisaka and Kanamaru 2013). Further to this, being a Professor did not slow down Fumio's own experimental output, with his engagement in a range of collaborative projects on topics as diverse as receptor biology (Mio et al. 2010), assembly of nanotechnology components (Yokoi et al. 2010; Inaba et al. 2012; Sanghamitra et al. 2014), hemoglobin allostery (Arisaka et al. 2011), crop protein analysis (Wadahama et al. 2012; Sato et al. 2015; Yamniuk et al. 2015), autophagy (Araki et al. 2013), amyloid analysis (Zhao et al. 2016; Hall et al. 2016), biopharmaceutical development (Iwura et al. 2014a, 2014b), AUC methodological development (Zhao et al. 2015) and thermostable enzymes (Tamakoshi et al. 2011; Chen et al. 2011; Ozawa et al. 2012) among many others (Huq et al. 2010; Yamasaki et al. 2010; Kanazawa et al. 2010; Sawada et al. 2011; Akita et al. 2012; Nomura et al. 2012; Ishii et al. 2012; Nozawa et al. 2013; Seio et al. 2013; Takei et al. 2014; Kumazaki et al. 2014; Owa et al. 2014; Iwura et al. 2014a, 2014b; Arai et al. 2015; Kurasawa et al. 2015). 


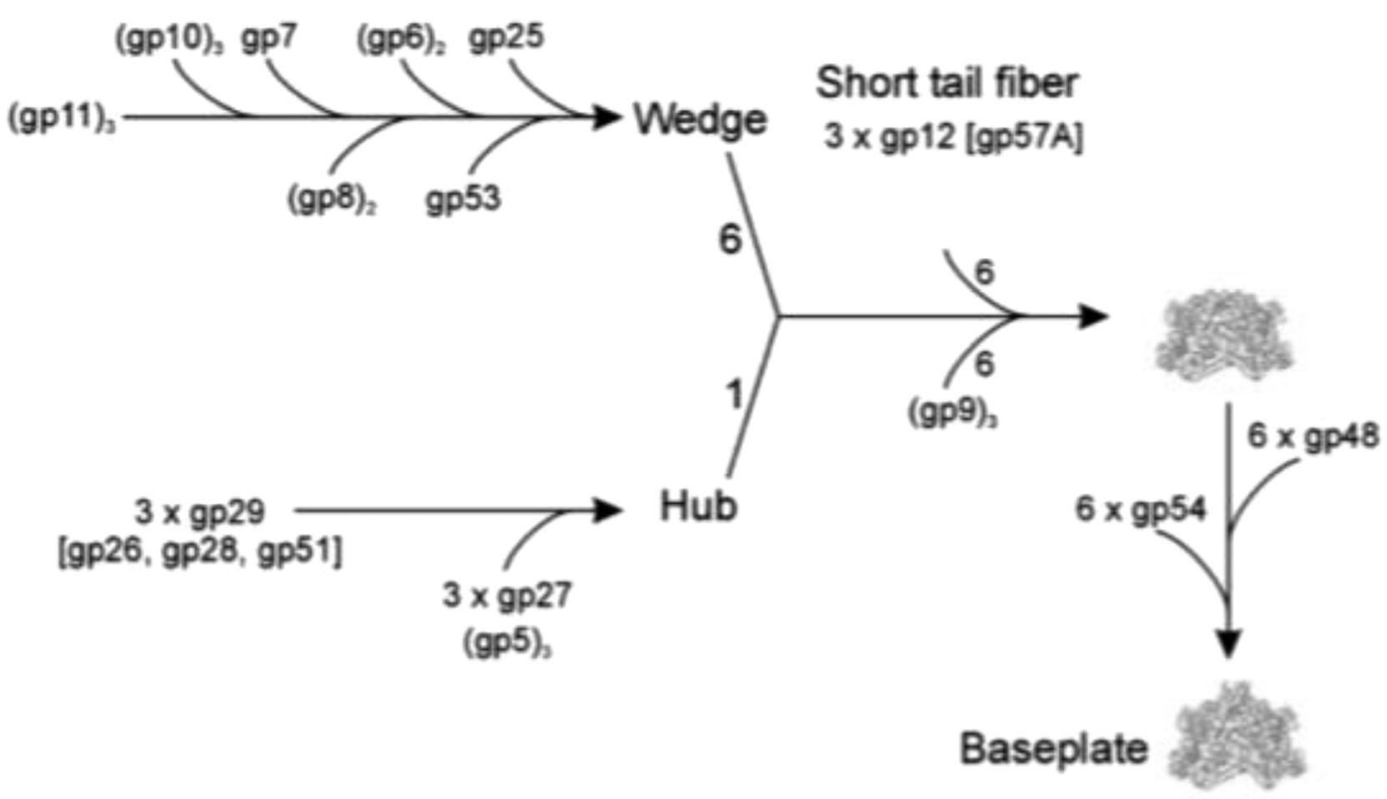

Table 1. Summary of the AUC-SV results of the purified individual proteins and the intermediate complexes

\begin{tabular}{|c|c|c|c|c|}
\hline Complex & $\begin{array}{l}\text { Sedimentation coefficient } \\
\text { Sed. coeff. (S) }\end{array}$ & Calculated Mw & Observed Mw & $f / f_{0}$ \\
\hline${ }^{\mathrm{H}} \mathrm{gp} 8$ (dimer) & 5.0 & 79,607 & 83,000 & 1.36 \\
\hline gp6 $^{\mathrm{H}}$ (dimer) & 6.0 & 152,552 & 145,000 & 1.59 \\
\hline 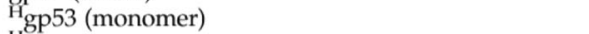 & 2.1 & 24,877 & 26,000 & 1.45 \\
\hline $\mathrm{H}_{\mathrm{gp} 25 \text { (monomer) }}^{\delta / 2}$ & 1.8 & 17,222 & 18,000 & 1.30 \\
\hline gp10-gp7- ${ }^{\mathrm{H}} \mathrm{gp} 8(3: 1: 2)$ & 12.1 & 397,518 & 384,000 & 1.53 \\
\hline gp10-gp7-gp8-gp6 $6^{\mathrm{H}}(3: 1: 2: 2)$ & 14.5 & 546,479 & 565,000 & 1.64 \\
\hline \multirow{2}{*}{ gp10-gp7-gp8-gp6 ${ }^{\mathrm{H}}-\mathrm{gp} 53$ (3:1:2:2:1) } & 15.0 & 569,445 & 518,000 & 1.51 \\
\hline & 43.7 & $3,416,670$ & $2,642,000$ & 1.53 \\
\hline \multirow[t]{2}{*}{ gp10-gp7-gp8-gp6 ${ }^{\mathrm{H}}-\mathrm{gp} 53-g p 25$ (3:1:2:2:1:1) } & 15.3 & 584,540 & 529,000 & 1.49 \\
\hline & 42.0 & $3,504,240$ & $2,297,000$ & 1.44 \\
\hline \multirow[t]{2}{*}{ gp11-gp10-gp7-gp8-gp6 ${ }^{\mathrm{H}}$-gp53-gp25 (3:3:1:2:2:1:1) } & 16.0 & 655,661 & 685,000 & 1.68 \\
\hline & 40.6 & $3,933,966$ & $2,554,000$ & 1.59 \\
\hline
\end{tabular}
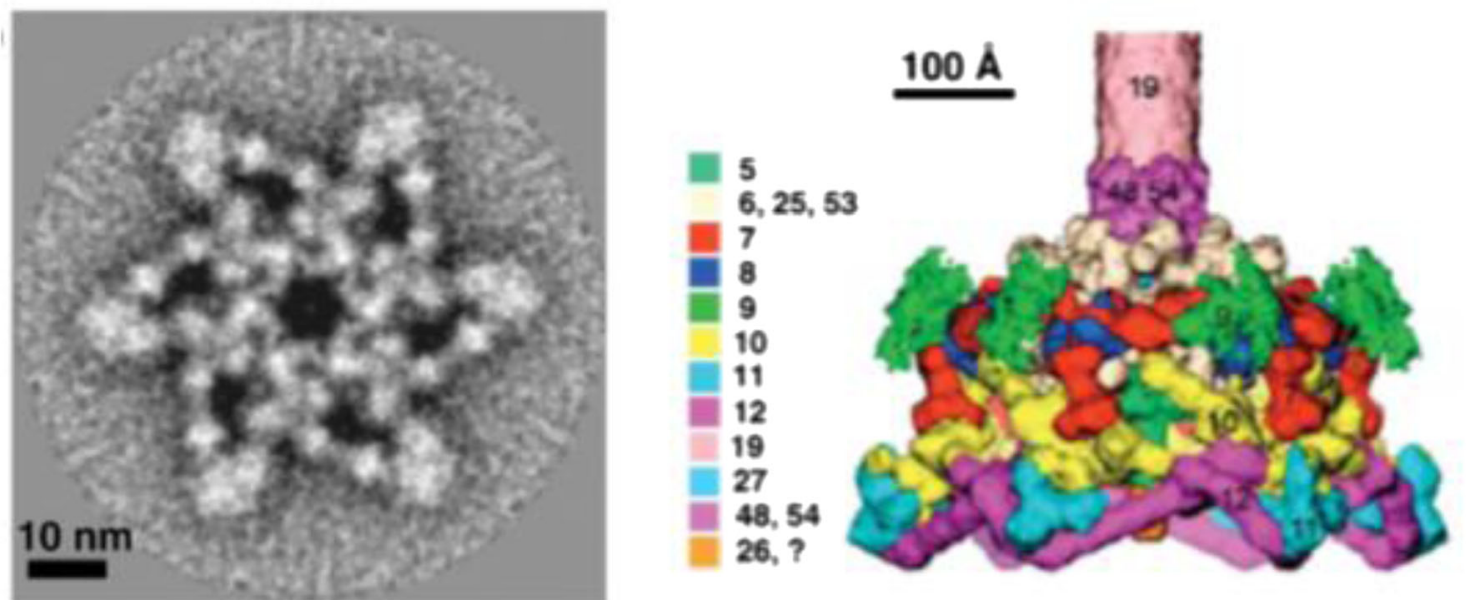

Fig. 10 Rules of assembly of many components of the complex T4 phage bio-nanomachine are determined by combinatorial mixing of the components. (Top) Assembly pathway and structure of the assembly of the wedge of the baseplate of phage T4 (reproduced with permission from Yap et al. 2010b). (Centre) Summary of the AUC-SV results of the purified individual proteins and their intermediate complexes - a finding that revealed the stoichiometry and mechanism of assembly (reproduced with permission from Yap et al. 2010a). (Bottom left) A reconstructed negatively stained EM image of the core-baseplate structure composed from the (gp10-gp7-gp8-gp6 ${ }^{\mathrm{H}}$-gp53-gp25) (reproduced with permission from Yap et al. 2010a). (Bottom right) Cross-section of the dome-shaped T4 bacteriophage baseplate along with identification of the position of each protein sub-component (reproduced with permission from Kostychenko et al. 2003) 
After retirement (2015-present) After finishing work at the mandatory age of 65, it is common for Japanese Professors at elite public institutions to take a 5 -year position at a private university where they may teach a limited number of courses and engage in research at a slightly more relaxed pace. Such a situation was important for both Fumio personally and also for his network of collaborators who depended upon him for help with a bevy of biophysical measurements. After finishing at the Tokyo Institute of Technology, Fumio took on such a retirement position at Nihon Daigaku (literally the University of Japan) - a traditional university that, in addition to the physical sciences, places a great focus on the teaching and research of Japanese culture and history. It is here that Fumio presently works in the laboratory of Prof. Kenji Ueda (Life Science Center of the School of Bioresource Science) dividing his time between teaching basic science glasses to undergraduates and engaging in collaborative experiments with colleagues throughout Japan on a range of protein science topics (Nishikawa et al. 2016; Saotome et al. 2016; Tsutsui et al. 2016; Arisaka et al. 2016).

\section{Scientific process-societies and service}

Part of what has made Fumio a valued academic colleague to those lucky enough to have known him has been his willingness to roll up his sleeves and engage with the necessary academic committee work and society and meeting organization duties. In regard to this aspect, we note Fumio's service to the Japanese Civil Service Exam Commission (2000-2004) a time during which he helped set the entrance exams for all incoming public servants. Among many other roles, we also highlight the following - his key role in the Japanese AUC Forum (2001-2010, from 2010-present the name has been changed to Biomolecular Interaction Analysis (BMIA) Internet Forum organized together with Assoc. Prof. Satoru Unzai and Prof. Susumu Uchiyama) through which a series of

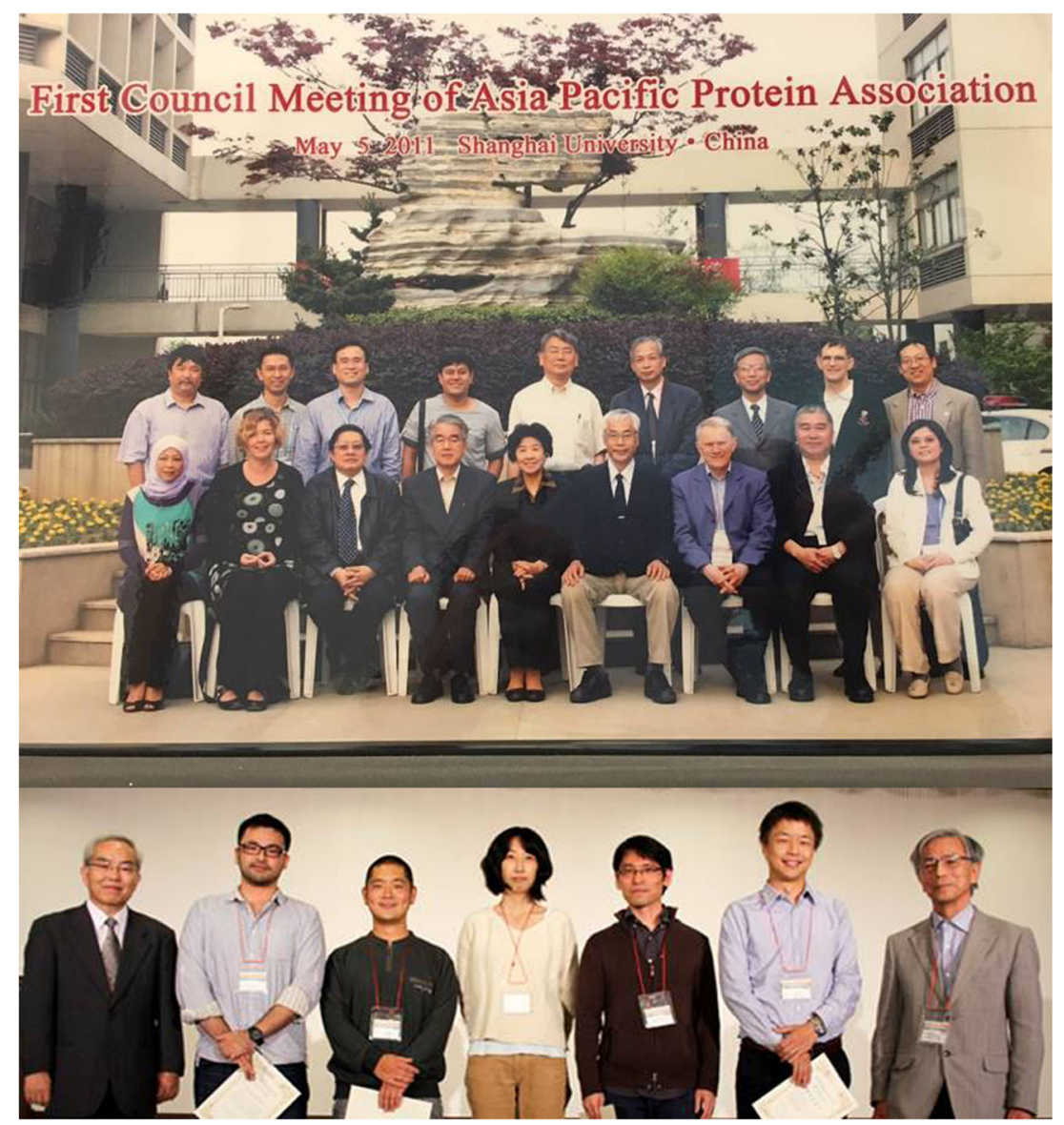

Fig. 11 Fumio has been a much appreciated colleague due to his very supportive and hardworking nature in the administration of research events and scientific bodies. (Top) Fumio in attendance as a founding members of the Asia Pacific Protein Association (APPA) 2011. APPA currently has over 15 member states throughout the region. Fumio is shown third from the top right. Other contributors to this special issue from the APPA council include Yuji Goto (fourth from bottom rightJapan), Haruki Nakamura (fourth from top right—Japan), Jianxing Song (top left-Singapore), Lemmuel Tayo (fourth from top leftPhilippines). More recent members of APPA who have contributed include Renwick Dobson (New Zealand) and Bambang Sugiharto (Indonesia). (Bottom) Together with the then Biophysical Society of Japan President Yoshinori Shichida (left), Fumio (right) presents a series of young investigator awards on behalf of the Biophysical Society of Japan (photo taken 2014) 
regular meetings were run under the title of 'BMIA Workshops', his long service to the Biophysical Society of Japan (BSJ) as a Senior Committee Member including a term as Vice President of the Society (2014-2015) and his long and active role as a committee member of the Protein Science Society of Japan (PSSJ) (also including a term as Vice President (2013-2014)). Finally, and importantly, we would like to note Fumio's pivotal role in founding and sustaining the Asia Pacific Protein Association (APPA) as a Japanese delegate to the organization (Fig. 11). It is in honour of this service that we have contributions from a number of fellow APPA council members (North et al. 2018; Tayo 2017; Sawitri et al. 2018; Song 2018; Goto et al. 2018).

\section{Life outside of science-hobbies, community}

Outside of science, Fumio is a committed husband to his wife Hiroko and devoted father and grandfather to his four sons and two granddaughters. A semi-professional flutist Fumio practices daily both modern and traditional forms. Although his audience is often only made up of late working graduate students and research fellows, Fumio has previously performed at nearby day care centres for the elderly along with exhibitions at hospitals for the sick. This love of music is also manifest in his membership and participation in a local Kamakura choir group as well as his performance in a Gregorian chanting group. The story would not be complete without noting Fumio's commitment to his Catholic faith - the roots of which can be traced back to his Jesuit based education during his high school days. Although deeply private in his devotion, various aspects of Fumio's life as a practicing Catholic can be seen in his volunteer service to the various community programs run through his church.

\section{Concluding remarks}

Whilst some scientists come onto the scene like a supernova, others burn at a more even rate during their careers, often providing more warmth and illumination over a longer time. Due to his unassuming and self-deprecating nature, Professor Fumio Arisaka can, in a crowd of more flamboyant colleagues, be easily pushed from the front of the stage. Never exploitative of junior colleagues, always happy to personally put effort into a collaboration and the least likely person to ever fight over an authorship position some might say that the basic kind and generous personality type exhibited by Prof. Fumio Arisaka was perhaps not optimized for success in today's community of professional scientists - in which a hard edge can get you a long way irrespective of knowledge or talent. Yet, despite this, Fumio Arisaka has successfully established an extremely rich and scientifically beneficial career in which his own thoughts and toil are on display in each and every publication. His consistently focussed long-time work in the field of phage biology has advanced our understanding to the point today that the DNA injection device of the T4 phage is being used as the basis for novel bionanomachines (e.g. Rossmann et al. 2004; Ueno et al. 2006; Yokoi et al. 2010; Yokoi et al. 2011; Sanghamitra et al. 2014; Inaba and Ueno 2018). On the human side, his career has touched a large number of scientists. Through a combination of his innate kindness and humbleness coupled with an underlying strength and determination, he has helped to make those around him both better scientists and better people.

Approaching the finishing line of an academic career, it is a victory to be able to receive the admiration and respect of colleagues who genuinely value both your human and scientific qualities. It is with this closing remark that we three, on behalf of all the contributors to this special issue,${ }^{21}$ collectively wish Professor Fumio Arisaka all the best on the occasion of his 70th birthday and express the fact that we very much look forward to his further counsel and scientific contributions over the coming years.

Acknowledgements The information in this foreword came from conversations enjoyed over a period of long friendship between the three authors and FA along with 2 days of focussed interview between DH and FA during a rainy period in Kawasaki Tokyo in the late August of 2017. The three Editors would like to thank Prof. Cris dos Remedios for his efforts in enabling this Festschrift to be part of the 2018 Biophysical Reviews issues. DH acknowledges the financial support in the form of an ANU Senior Research Fellowship and the Osaka University Associate Professor cross-appointment scheme. DH and JT would like to jointly acknowledge Osaka University for funds directly supporting the Laboratory of Multiscale Structural Biology at the Institute for Protein Research. HN gratefully acknowledges funding support from the Protein Data Base of Japan (PDBj).

\section{Compliance with ethical standards}

Conflict of interest Damien Hall declares that he has no conflicts of interest. Junichi Takagi declares that he has no conflicts of interest. Haruki Nakamura declares that he has no conflicts of interest.

Ethical approval This article does not contain any studies with human participants or animals performed by any of the authors.

\section{References}

Abe M, Hori H, Nakanishi T, Arisaka F, Ogasawara T, Sawasaki T, Kitamura M, Endo Y (2004) Application of cell-free translation systems to studies of cofactor binding proteins. Nucl Acids Symp Ser (Oxf) 48:143-144

Abe M, Ohno S, Yokogawa T, Nakanishi T, Arisaka F, Hosoya T, Hiramatsu T, Suzuki M, Ogasawara T, Sawasaki T, Nishikawa K, Kitamura M, Hori H, Endo Y (2007) Detection of structural changes in a cofactor binding protein by using a wheat germ cell-free protein

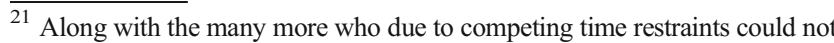
make the deadline for this issue.
} 
synthesis system coupled with unnatural amino acid probing. Proteins 67:643-652

Absar N, Yeasmin T, Raza MS, Sarkar SK, Arisaka F (2005) Single step purification, characterization and N-terminal sequences of a mannose specific lectin from mulberry seeds. Protein J 24:369-377

Absar N, Hasan S, Arisaka F (2008) Purification, characterization and Nterminal sequences alignment of a mannose specific protein purified from Potca fish. Tetraodon patoca Protein J 27:97-104

Akazawa-Ogawa Y, Nagai H and Hagihara Y (2018) Heat denaturation of the antibody, a multi-domain protein. Biophys Rev. (current issue)

Akhter T, Zhao L, Kohda A, Mio K, Kanamaru S, Arisaka F (2007) The neck of bacteriophage T4 is a ring-like structure formed by a heterooligomer of gp13 and gp14. Biochim Biophys Acta 1774:1036-1043

Akita F, Higashiura A, Shimizu T, Pu Y, Suzuki M, Uehara-Ichiki T, Sasaya T, Kanamaru S, Arisaka F, Tsukihara T, Nakagawa A, Omura T (2012) Crystallographic analysis reveals octamerization of viroplasm matrix protein P9-1 of Rice black streaked dwarf virus. J Virol 86:746-756

Ali SA, Iwabuchi N, Matsui T, Hirota K, Kidokoro S, Arai M, Kuwajima K, Schuck P, Arisaka F (2001) Reversible and fast association equilibria of a molecular chaperone, gp57A, of bacteriophage T4. Biophys J 85:2606-2618

Ando T (2018) High-speed atomic force microscopy and its future prospects. Biophys Rev. (current issue)

Arai M (2018a) Unified understanding of folding and binding mechanisms of globular and intrinsically disordered proteins. Biophys Rev. (current issue)

Arai R (2018b) Hierarchical design of artificial proteins and complexes toward synthetic structural biology. Biophys Rev. (current issue)

Arai T, Kimata S, Mochizuki D, Hara K, Zako T, Odaka M, Yohda M, Arisaka F, Kanamaru S, Matsumoto T, Yajima S, Sato J, Kawasaki S, Niimura Y (2015) NADH oxidase and alkyl hydroperoxide reductase subunit $\mathrm{C}$ (peroxiredoxin) from Amphibacillus xylanus form an oligomeric assembly. FEBS Open Bio 7:124-131

Arakawa T (2018) Protein solvent interaction. Biophys Rev. (current issue)

Arakawa T, Niikura T, Tajima H, Arisaka F, Kita Y (2007) Structure analysis of activity-dependent neurotrophic factor 9 by circular dichroism and sedimentation equilibrium. J Mol Neurosci 33:262-267

Arakawa T, Niikura T, Arisaka F, Kita Y (2008) Activity-dependent neurotrophic factor, $\mathrm{ADNF}$, determines the structure characteristics of Colivelin, a fusion protein of ADNF9 and Humanin analog. J Pept Sci 14:631-636

Arakawa T, Niikura T, Arisaka F, Kita Y (2009a) Short neuroprotective peptides, ADNF9 and NAP, are structurally disordered and monomeric in PBS. Int J Biol Macromol 45:8-11

Arakawa T, Niikura T, Kita Y, Arisaka F (2009b) Structure analysis of short peptides by analytical ultracentrifugation: review. Drug Discov Ther 3:208-214

Araki Y, Ku WC, Akioka M, May AI, Hayashi Y, Arisaka F, Ishihama Y, Ohsumi Y (2013) Atg38 is required for autophagy-specific phosphatidylinositol 3-kinase complex integrity. J Cell Biol 203:299-313

Arisaka S (1936) Heiki-ko. (translation ' a study on weapons'). Publishers Tokyo, Yuzan-Koku

Arisaka F (1977) Allosteric Properties and the Association Equilibria of Hemocyanin from Calianassa Californiensis Ph.D. Thesis, Oregon State University

Arisaka F (1992) Replication and gene expression of T4 phage DNA. Tanpakushitsu Kakusan Koso 37:2570-2579

Arisaka F (1994a) Protein-protein interaction. Tanpakushitsu Kakusan Koso. 39:1036-1051

Arisaka F (1994b) Ultracentrifugation. Tanpakushitsu Kakusan Koso. 39: 1734-1756

Arisaka F (1996) Standard Seikagaku (Standard Biochemistry). Shokabo (in Japanese)

Arisaka F (1998a) Analytical ultracentrifugation. Tanpakushitsu Kakusan Koso. 43:2024-2032
Arisaka F (1998b) Introduction to analytical ultracentrifugation and its new development. Tanpakushitsu Kakusan Koso. 43:2145-2152

Arisaka F (1998c) Sedimentation equilibrium. Tanpakushitsu Kakusan Koso. 43:2238-2244

Arisaka F (1999) Applications and future perspectives of analytical ultracentrifugation. Tanpakushitsu Kakusan Koso. 44:82-91

Arisaka F (2001) Self-assembly and phage-encoded molecular chaperones of bacteriophage T 4. Uirusu 51:57-62

Arisaka F (2004a) Analytical ultracentrifugation. Tanpakushitsu Kakusan Koso. 49:1660-1667

Arisaka F (2004b) Introduction to Protein Science for Bioscience, Shokabo (in Japanese)

Arisaka F (2005) Assembly and infection process of bacteriophage T4. Chaos 15:047502

Arisaka F (2015) Yoku Wakaru Standard Seikagaku (Easily Understandable Standard Biochemistry), 1st edition, Shokabo (in Japanese)

Arisaka F (2018) Forty Years of Research on the Assembly and Infection Process of Bacteriophage. Biophys Rev. (current issue)

Arisaka F, Kanamaru S (2013) Protein interactions in the assembly of the tail of bacteriophage T4. Biophys Rev 5:79-84

Arisaka F, Van Holde KE (1979) Allosteric properties and the association equilibria of Hemocyanin from Callianassa Californiensis. J Mol Biol 134:41-73

Arisaka F, Kawamura M, Maruyama K (1973) Changes in the distribution of particle length of $\mathrm{F}$-actin transformed from mg-polymer. $\mathrm{J}$ Biochem 73:1211-1215

Arisaka F, Noda H, Maruyama K (1975) Kinetic analysis of the polymerization process of actin. Biochimica Biophysica Acta 400:263-274

Arisaka F, Tschopp J, van Driel R, Engel J (1979) Reassembly of the bacteriophage $\mathrm{T} 4$ tail from the Corebaseplate and the monomeric sheath protein P18: a cooperative association process. J Mol Biol 132:369-386

Arisaka F, Engel J, Klump H (1980) Contraction and dissociation of the bacteriophage T4 tail sheath induced by heat and urea. Prog Clin Biol Res 64:365-379

Arisaka F, Engel J, Klump H (1981) Contraction and dissociation of the bacteriophage T4 tail sheath induced by heat and urea. Prog Clin Biol Res 64:365-379

Arisaka F, Nakako T, Kumazaki T, Ishii SI (1987) Primary structure of the tail sheath protein of bacteriophage T4 and its gene. J Protein Chem 6:245-251

Arisaka F, Ishimoto L, Kassavetis G, Kumazaki T, Ishii S (1988a) Nucleotide sequence of the tail tube structural gene of bacteriophage T4. J Virol 62:882-886

Arisaka F, Nakako T, Takahashi H, Ishii S (1988b) Nucleotide sequence of the tail sheath gene of bacteriophage $\mathrm{T} 4$ and amino acid sequence of its product. J Virol 62:1186-1193

Arisaka F, Takeda S, Funane K, Nishijima N, Ishii S (1990) Structural studies of the contractile tail sheath protein of bacteriophage T4. 2 . Structural analyses of the tail sheath protein, Gp18, by limited proteolysis, immunoblotting, and immunoelectron microscopy. Biochemistry 29:5057-5062

ArisakaF, Kanamaru S, Leiman P, Rossmann MG(2003) The tail lysozyme complex of bacteriophage T4. Int J Biochem Cell Biol 35:16-21

Arisaka F, Niikura T, Arakawa T, Kita Y (2008) The structure analysis of Humanin analog, AGA-(C8R)HNG17, by circular dichroism and sedimentation equilibrium: comparison with the parent molecule. Int J Biol Macromol 43:88-93

Arisaka F, Arakawa T, Niikura T, Kita Y (2009) Active form of neuroprotective Humanin, $\mathrm{HN}$, and inactive analog, S7A-HN, are monomeric and disordered in aqueous phosphate solution at $\mathrm{pH}$ 6.0; no correlation of solution structure with activity. Protein Peptide Lett 16:132-137 
Arisaka F, Nagai Y, Nagai M (2011) Dimer-tetramer association equilibria of human adult hemoglobin and its mutants as observed by analytical ultracentrifugation. Methods 54:175-180

Arisaka F, Yap ML, Kanamaru S, Rossmann MG (2016) Molecular assembly and structure of the bacteriophage T4 tail. Biophys Rev 8: 385-396

Chatani E., and Yamamoto N. (2018) Recent progress on understanding the mechanisms of amyloid nucleation. Biophys Revi. (current issue)

Chen S, Ye F, Chen Y, Chen Y, Zhao H, Yatsunami R, Nakamura S, Arisaka F, Xing XH (2011) Biochemical analysis and kinetic modeling of the thermal inactivation of MBP-fused heparinase I: implications for a comprehensive thermostabilization strategy. Biotechnol Bioeng 108:1841-1851

Daum B, Quax TE, Sachse M, Mills DJ, Reimann J, Yildiz Ö, Häder S, Saveanu C, Forterre P, Albers SV, Kühlbrandt W (2014) Selfassembly of the general membrane-remodeling protein PVAP into sevenfold virus-associated pyramids. Proc Natl Acad Sci 111:3829-3834

Dowah ASA and Clokie MRJ (2018) Review of the nature, diversity and structure of bacteriophage receptor binding proteins that target Gram-positive bacteria. Biophys Rev. (current issue)

Ekimoto T and Ikeguchi M (2018) Multiscale molecular dynamics simulations of rotary motor proteins. Biophys Rev. (current issue)

Engel J, Chen HT, Prockop DJ, Klump H (1977) The triple helix $\rightleftharpoons$ coil conversion of collagen-like polytripeptides in aqueous and nonaqueous solvents. Comparison of the thermodynamic parameters and the binding of water to (L-pro-L-pro-Gly) $\mathrm{n}$ and (L-pro-L-Hyp-Gly) $\mathrm{n}$. Biopolymers 16:601-622

Fokine A, Zhang Z, Kanamaru S, Bowman VD, Aksyuk AA, Arisaka F, Rao VB, Rossmann MG (2013) The molecular architecture of the bacteriophage T4 neck. J Mol Biol 425:1731-1744

Frellesvig B (2010) A history of the Japanese language. Oxford University Press, Oxford, p 44

Fujiwara T, and Masuda S (2018) Light-induced chromophore and protein responses and mechanical signal transduction of BLUF proteins. Biophys Rev. (current issue)

Furutani Y (2018) Ion-protein interactions of a potassium ion channel studied by attenuated total reflection Fourier transform infrared spectroscopy. Biophys Rev. (current issue)

Gaillard G (2004) The Routledge dictionary of anthropologists. Routledge, Oxford, p 269

Goto Y., Adachi M., Muta H., and So M. (2018) Salt-induced formations of partially folded intermediates and amyloid fibrils suggests a common underlying mechanism. Biophysical reviews (current issue)

Hall D, Zhao R, Dehlsen I, Bloomfield N, Williams SR, Arisaka F, Goto Y, Carver JA (2016) Protein aggregate turbidity: simulation of turbidity profiles for mixed-aggregation reactions. Anal Biochem 498:78-94

Hara S, Motohashi K, Arisaka F, Romano PG, Hosoya-Matsuda N, Kikuchi N, Fusada N, Hisabori T (2006) Thioredoxin-h1 reduces and reactivates the oxidized cytosolic malate dehydrogenase dimer in higher plants. J Biol Chem 281:32065-32071

Hoque M, Ishizu K, Matsumoto A, Han SI, Arisaka F, Takayama M, Suzuki K, Kato K, Kanda T, Watanabe H, Handa H (1999a) Nuclear transport of the major capsid protein is essential for adeno-associated virus capsid formation. J Virol 73:7912-7915

Hoque M, Shimizu N, Ishizu KI, Yajima H, Arisaka F, Suzuki K, Watanabe H, Handa H (1999b) Chimeric virus-like particle formation of adeno-associated virus. Biochem Biophys Res Commun 266:371-376

Huq S, Sueoka K, Narumi S, Arisaka F, Nakamoto H (2010) Comparative biochemical characterization of two GroEL homologs from the cyanobacterium Synechococcus Elongatus PCC 7942. Biosci Biotechnol Biochem 74:2273-2280

Huurdeman A (2003) The worldwide history of telecommunications. John Wiley and Sons, Hoboken, p 281

Hyman P and van Raaij M (2018) Bacteriophage T4 long tail fiber domains. Biophys Rev (current issue)
Ikai A, Yoshimura K, Arisaka F, Ritani A, Imai K (1993) Atomic force microscopy of bacteriophage T4 and its tube-baseplate complex. FEBS Lett 326:39-41

Imada K (2018) Bacterial flagellar axial structure and its construction. Biophys Rev. (current issue)

Inaba H and T Ueno (2018) Artificial bio-nanomachines based on protein needles derived from bacteriophage T4. Biophys Rev. (current issue)

Inaba H, Kanamaru S, Arisaka F, Kitagawa S, Ueno T (2012) Semisynthesis of an artificial scandium(III) enzyme with a $\beta$-helical bio-nanotube. Dalton Trans 41:11424-11427

Inamori K, Saito T, Iwaki D, Nagira T, Iwanaga S, Arisaka F, Kawabata S (1999) A newly identified horseshoe crab lectin with specificity for blood group a antigen recognizes specific $\mathrm{O}$-antigens of bacterial lipopolysaccharides. J Biol Chem 274:3272-3278

Inamori K, Saito T, Iwaki D, Nagira T, Iwanaga S, Arisaka F, Kawabata S (2001) Horseshoe crab hemocyte-derived lectin recognizing specific O-antigens of lipopolysaccharides. Adv Exp Med Biol 484:185-190

Inoue S, Tanaka K, Arisaka F, Kimura S, Ohtomo K, Mizuno S (2000) Silk fibroin of Bombyx Mori is secreted, assembling a high molecular mass elementary unit consisting of $\mathrm{H}$-chain, L-chain, and P25, with a 6:6:1 molar ratio. J Biol Chem 275:40517-40528

Ishii R, Isogaya K, Seto A, Koinuma D, Watanabe Y, Arisaka F, Yaguchi S, Ikushima H, Dohmae N, Miyazono K, Miyazawa K, Ishitani R, Nureki O (2012) Structure of a dominant-negative helix-loop-helix transcriptional regulator suggests mechanisms of autoinhibition. EMBO J 31:2541-2552

Iwura T, Fukuda J, Yamazaki K, Arisaka F (2014a) Conformational stability, reversibility and heat-induced aggregation of $\alpha$-1-acid glycoprotein. J Biochem 156:345-352

Iwura T, Fukuda J, Yamazaki K, Kanamaru S, Arisaka F (2014b) Intermolecular interactions and conformation of antibody dimers present in IgG1 biopharmaceuticals. J Biochem 155:63-71

Kanamaru S, Arisaka F (2002) The structural biology and infection mechanism of bacteriophage T4. Seikagaku 74:131-135

Kanamaru S, Arisaka F (2005) Structure and infection mechanism of bacteriophages. Tanpakushitsu Kakusan Koso. 50:1341-1348

Kanamaru S, Arisaka F (2007) Structural biology of bacteriophage. Tanpakushitsu Kakusan Koso. 52:1069-1074

Kanamaru S, Gassner NC, Ye N, Takeda S, Arisaka F (1999) The Cterminal fragment of the precursor tail lysozyme of bacteriophage T4 stays as a structural component of the baseplate after cleavage. J Bacteriol 181:2739-2744

Kanamaru S, Leiman PG, Kostyuchenko VA, Chipman PR, Mesyanzhinov VV, Arisaka F, Rossmann MG (2002) Structure of the cell-puncturing device of bacteriophage T4. Nature 415:553-557

Kanamaru S, Ishiwata Y, Suzuki T, Rossmann MG, Arisaka F (2005) Control of bacteriophage T4 tail lysozyme activity during the infection process. J Mol Biol 346:1013-1020

Kanazawa T, Ren S, Maekawa M, Hasegawa K, Arisaka F, Hyodo M, Hayakawa Y, Ohta H, Masuda S (2010) Biochemical and physiological characterization of a BLUF protein-EAL protein complex involved in blue light-dependent degradation of cyclic diguanylate in the purple bacterium Rhodopseudomonas palustris. Biochemistry 49:10647-10655

Kao SH, McClain WH (1980) Baseplate protein of bacteriophage T4 with both structural and lytic functions. J Virol 34:95-103

Kato S, Matsui T, Gatsogiannis C and Tanaka Y (2018a) Molluscan Hemocyanin: Structure, Evolution, and Physiology. Biophys Rev. (current issue)

Kato Y, Miyakawa T and Tanokura M (2018b) Overview of the mechanism of cytoskeletal motors based on structure. Biophys Rev. (current issue)

Katoh K and Satoh T (2018) Structural insights on the dynamics of proteasome formation. Biophys Rev. (current issue) 
Kawabata T, Arisaka F, Nishikawa K (2000) Structural/functional assignment of unknown bacteriophage T4 proteins by iterative database searches. Gene 259:223-233

Kelman P (2001) Protesting the national identity: the cultures of protest in 1960s Japan. Chapter 6. Ph.D. Thesis. University of Sydney

Kita Y, Niikura T, Arisaka F, Arakawa T (2008) The complex structure transition of Humanin peptides by sodium dodecylsulfate and trifluoroethanol. Protein and Peptide Lett 15:510-515

Kitao A., and Hata H. (2018) Molecular Dynamics Simulation of Bacterial Flagella. Biophys Rev. (current issue)

Kohda D (2018) Multiple partial recognitions in dynamic equilibrium in the binding sites of proteins form the molecular basis of promiscuous recognition of structurally diverse ligands. Biophys Rev. (current issue)

Kojima S, Kuriki Y, Sato Y, Arisaka F, Kumagai I, Takahashi S, Miura K (1996) Synthesis of alpha-helix-forming peptides by gene engineering methods and their characterization by circular dichroism spectra measurements. Biochim Biophys Acta 1294:129-137

Koshiyama T, Yokoi N, Ueno T, Kanamaru S, Nagano S, Shiro Y, Arisaka F, Watanabe Y (2008) Molecular design of heteroprotein assemblies providing a bionanocup as a chemical reactor. Small 4:50-54

Koshiyama T, Ueno T, Kanamaru S, Arisaka F, Watanabe Y (2009) Construction of an energy transfer system in the bio-nanocup space by heteromeric assembly of gp 27 and gp5 proteins isolated from bacteriophage T4. Org Biomol Chem 7:2649-2654

Kostyuchenko VA, Leiman PG, Chipman PR, Kanamaru S, van Raaij MJ, Arisaka F, Mesyanzhinov VV, Rossmann MG (2003) Threedimensional structure of bacteriophage T4 baseplate. Nat Struct Mol Biol 10:688-693

Kostyuchenko VA, Chipman PR, Leiman PG, Arisaka F, Mesyanzhinov VV, Rossmann MG (2005) The tail structure of bacteriophage T4 and its mechanism of contraction. Nat Struct Mol Biol 12:810-813

Kosukegawa A, Arisaka F, Takayama M, Yajima H, Kaidow A, Handa H (1996) Purification and characterization of virus-like particles and pentamers produced by the expression of SV40 capsid proteins in insect cells. Biochim Biophys Acta 1290:37-45

Kumar-Sarkar S, Takeda Y, Kanamaru S, Arisaka F (2006) Association and dissociation of the cell puncturing complex of bacteriophage $\mathrm{T} 4$ is controlled by both $\mathrm{pH}$ and temperature. Biochim Biophys Acta 1764:1487-1492

Kumazaki T, Nakako T, Arisaka F, Ishii S (1986) A novel method for selective isolation of C-terminal peptides from tryptic digests of proteins by immobilized anhydrotrypsin: application to structural analyses of the tail sheath and tube proteins from bacteriophage T4. Proteins 1:100-107

Kumazaki K, Chiba S, Takemoto M, Furukawa A, Nishiyama K, Sugano Y, Mori T, Dohmae N, Hirata K, Nakada-Nakura Y, Maturana AD, Tanaka Y, Mori H, Sugita Y, Arisaka F, Ito K, Ishitani R, Tsukazaki T, Nureki O (2014) Structural basis of sec-independent membrane protein insertion by YidC. Nature 509:516-520

Kurasawa M, Arisaka F, Ozeki T (2015) Asymmetrically fused polyoxometalate-silver alkynide composite cluster. Inorg Chem $54: 1650-1654$

Kuroda Y (2018) Biophysical studies of protein solubility and amorphous aggregation by systematic mutational analysis and a helical polymerization model. Biophys Rev. (current issue)

Leiman PG, Kanamaru S, Mesyanzhinov VV, Arisaka F, Rossmann MG (2003) Structure and morphogenesis of bacteriophage T4. Cell Mol Life Sci 60:2356-2370

Leiman PG, Arisaka F, van Raaij MJ, Kostyuchenko VA, Aksyuk AA, Kanamaru S, Rossmann MG (2010) Morphogenesis of the T4 tail and tail fibers. Virol J 7:355

Makino T, Morii H, Shimizu T, Arisaka F, Kato Y, Nagata K, Tanokura M (2007) Reversible and irreversible coiled coils in the stalk domain of ncd motor protein. Biochemistry 46:9523-9532

Maruyama K, Katsura K, Arisaka F (1973) Linear aggregation of muscle protein. Tanpakushitsu Kakusan Koso. 18:547-557
Maruyama K, Itoh Y, Arisaka F (1986) Circular dichroism spectra show abundance of beta-sheet structure in connectin, a muscle elastic protein. FEBS Lett 202:353-355

Matsuda Y, Koshiba T, Osaki T, Suyama H, Arisaka F, Toh Y, Kawabata S (2007) An arthropod cuticular chitin-binding protein endows injured sites with transglutaminase-dependent mesh. J Biol Chem 282: 37316-37324

Matsui T, Griniuviené B, Goldberg E, Tsugita A, Tanaka N, Arisaka F (1997) Isolation and characterization of a molecular chaperone, gp57A, of bacteriophage T4. J Bacteriol 179:1846-1851

Miller KI, Eldred NW, Arisaka F, Van Holde KE (1977) Structure and function of hemocyanin from thalassinid shrimp. J Comp Physiol 115:171-184

Miller ES, Kutter E, Mosig G, Arisaka F, Kunisawa T, Rüger W (2003) Bacteriophage T4 genome. Microbiol Mol Biol Rev 67:86-156

Mima J (2018) Reconstitution of membrane tethering mediated by Rabfamily small GTPases. Biophys Rev. (current issue)

Mio K and Sato C (2018) Lipid environment of membrane proteins in cryo-EM based structural analysis. Biophys Rev. (current issue)

Mio K, Kubo Y, Ogura T, Yamamoto T, Arisaka F, Sato C (2008) The motor protein prestin is a bullet-shaped molecule with inner cavities. J Biol Chem 283:1137-1145

Mio K, Mio M, Arisaka F, Sato M, Sato C (2010) The C-terminal coiledcoil of the bacterial voltage-gated sodium channel $\mathrm{NaChBac}$ is not essential for tetramer formation, but stabilizes subunit-to-subunit interactions. Prog Biophys Mol Biol 103:111-121

Mitsutake A, Takano H (2018) Relaxation mode analysis for molecular dynamics simulations of proteins. Biophys Rev. https://doi.org/10. 1007/s12551-018-0406-7

Mizobata T and Kawata Y (2018) The versatile mutational "repertoire" of E. coli GroEL, a multi-domain chaperonin nanomachine. Biophys Rev. (current issue)

Mizohata, Nakane T., Fukuda Y., Nango E., and Iwata S. (2018) Serial femtosecond crystallography at SACLA: Breakthrough to dynamic structural biology. Biophys Rev. (current issue)

Morii H, Takenawa T, Arisaka F, Shimizu T (1997) Identification of kinesin neck region as a stable alpha-helical coiled coil and its thermodynamic characterization. Biochemistry 36:1933-1942

Morimoto K, Yamashita E, Kondou Y, Lee SJ, Arisaka F, Tsukihara T, Nakai M (2006) The asymmetric IscA homodimer with an exposed [2Fe-2S] cluster suggests the structural basis of the Fe-S cluster biosynthetic scaffold. J Mol Biol 360:117-132

Myszka DG, Abdiche YN, Arisaka F, Byron O, Eisenstein E, Hensley P, Thomson JA, Lombardo CR, Schwarz F, Stafford W, Doyle ML (2003) The ABRF-MIRG'02 study: assembly state, thermodynamic, and kinetic analysis of an enzyme/inhibitor interaction. J Biomol Technol 14:247-269

Nagai M, Mizusawa N, Kitagawa T and Nagatomo S (2018) A role of heme side-chains of human hemoglobin in its function revealed by circular dichroism and resonance Raman spectroscopy. Biophys Rev. (current issue)

Nakagawa H, Arisaka F, Ishii S (1985) Isolation and characterization of the bacteriophage T4 tail-associated lysozyme. J Virol 54:460-466

Nakagawa A, Miyazaki N and Higashiura A (2018) Hierarchical structure assembly model of Rice dwarf virus particle formation. Biophys Rev. (current issue)

Nakamura H, Arisaka F (2005) Protein Shape and Properties (New Biophysics Series 1). Kyoritsu-Shuppann (in Japanese)

Nemoto M, Mio K, Kanamaru S, Arisaka F (2008) ORF334 in vibrio phage KVP40 plays the role of gp27 in T4 phage to form a heterohexameric complex. J Bacteriol 190:3606-3612

Nishikawa H, Hayashi T, Arisaka F, Senda T, Hatakeyama M (2016) Impact of structural polymorphism for the helicobacter pylori CagA oncoprotein on binding to polarity-regulating kinase PAR1b. Sci Rep 6:30031 
Nishikawa K, Kinjo AR (2018) Mechanism of evolution by genetic assimilation: Equivalence and independence of genetic mutation and epigenetic modulation in phenotypic expression. Biophys Rev. (current issue)

Nishima W, Kanamaru S, Arisaka F, Kitao A (2011) Screw motion regulates multiple functions of T4 phage protein gene product 5 during cell puncturing. J Am Chem Soc 133:13571-13576

Nogi T (2018) How multi-scale structural biology elucidated contextdependent variability in ectodomain conformation along the ligand capture and release cycle for LDLR family members. Biophys Rev (current issue)

Nomura N, Honda T, Baba K, Naganuma T, Tanzawa T, Arisaka F, Noda M, Uchiyama S, Tanaka I, Yao M, Uchiumi T (2012) Archaeal ribosomal stalk protein interacts with translation factors in a nucleotide-independent manner via its conserved $\mathrm{C}$ terminus. Proc Nat Acad Sci USA 109:3748-3753

North RA, Horne CR, Davies JS, Remus DM, Muscroft-Taylor AC, Goyal P, Wahlgren WY, Ramaswamy S, Friemann R, Dobson RCJ (2018) "Just a spoonful of sugar...": import of sialic acid across bacterial cell membranes. Biophys Rev. (current issue)

Nozawa K, Ishitani R, Yoshihisa T, Sato M, Arisaka F, Kanamaru S, Dohmae N, Mangroo D, Senger B, Becker HD, Nureki O (2013) Crystal structure of Cexlp reveals the mechanism of tRNA trafficking between nucleus and cytoplasm. Nucleic Acids Res 41:3901-3914

Ogawa T and Hirokawa N (2018) Multiple Analyses of Protein Dynamics in Solution. Biophys Rev. (current issue)

Okabe M, Tomita K, Ishitani R, Ishii R, Takeuchi N, Arisaka F, Nureki O, Yokoyama S (2003) Divergent evolutions of trinucleotide polymerization revealed by an archaeal CCA-adding enzyme structure. EMBO J 22:5918-5927

Okamoto K, Hiroshima M, and Sako Y (2018) Single-molecule fluorescence-based analysis of protein conformation, interaction, and oligomerization in cellular systems. Biophys Rev. (current issue)

Onaga L (2015) More than metamorphosis: the silkworm experiments of Toyama Kametaro and his cultivation of genetic thought in Japan's sericultural practices, 1894-1918. Chapter 20. In: New perspectives on the history of life sciences and agriculture. Phillips, D., and Kingsland, S. Springer International, Cham, pp 418

Oosawa F, Asakura S (1975) Thermodynamics of the polymerization of protein. Academic Press, New York

Oosawa F, Kasai M (1962) A theory of linear and helical aggregations of macromolecules. J Mol Biol 4:10-21

Oshima T, Imahori K (1974) Description of Thermus thermophilus (Yoshida and Oshima) comb. nov., a nonsporulating thermophilic bacterium from a Japanese thermal spa. Int J Syst Evol Microbiol $24: 102-112$

Owa M, Furuta A, Usukura J, Arisaka F, King SM, Witman GB, Kamiya R, Wakabayashi K (2014) Cooperative binding of the outer armdocking complex underlies the regular arrangement of outer arm dynein in the axoneme. Proc Nat Acad Sci U.S.A 111:9461-9466

Ozawa Y, Siddiqui MA, Takahashi Y, Urushiyama A, Ohmori D, Yamakura F, Arisaka F, Imai T (2012) Indolepyruvate ferredoxin oxidoreductase: an oxygen-sensitive iron-sulfur enzyme from the hyperthermophilic archaeon Thermococcus profundus. J Biosci Bioeng 114:23-27

Phillips-Jones M.K., and Harding S.J. (2018) Antimicrobial resistance (AMR) Nanomachines - mechanisms for fluoroquinolone and Glycopeptide recognition, Efflux and Deactivation Biophysical Reviews (current issue)

Powell D, Franklin J, Arisaka F, Mosig G (1990) Bacteriophage T4 DNA packaging genes 16 and 17. Nucleic Acids Res 18:4005

Quax TEF and Daum B (2018) Structure and assembly mechanism of virus associated pyramids. Biophys Rev. (current issue)

Rivas G and Minton AP (2018) Toward an understanding of biochemical equilibria within living cells. Biophys Rev. (current issue)
Roberts AJ, Numata N, Walker ML, Kato YS, Malkova B, Kon T, Ohkura R, Arisaka F, Knight PJ, Sutoh K, Burgess SA (2009) $\mathrm{AAA}+$ ring and linker swing mechanism in the dynein motor. Cell 136:485-495

Rossmann MG (2018) My happy years of collaboration with Fumio Arisaka. Biophys Rev. (current issue)

Rossmann MG, Mesyanzhinov VV, Arisaka F, Leiman PG (2004) The bacteriophage T4 DNA injection machine. Curr Opin Struc Biol 14: $171-180$

Rossmann MG, Arisaka F, Battisti AJ, Bowman VD, Chipman PR, Fokine A, Hafenstein S, Kanamaru S, Kostyuchenko VA, Mesyanzhinov VV, Shneider MM, Morais MC, Leiman PG, Palermo LM, Parrish CR, Xiao C (2007) From structure of the complex to understanding of the biology. Acta Crystallogr D Biol Crystallogr 63:9-16

Sadaie M, Kawaguchi R, Ohtani Y, Arisaka F, Tanaka K, Shirahige K, Nakayama J (2008) Balance between distinct HP1 family proteins controls heterochromatin assembly in fission yeast. Mol Cell Biol 28:6973-6988

Sahlan M, Zako T and Yohda M (2018) Prefoldin, a jellyfish-like molecular chaperone: Functional cooperation with a group II chaperonin and beyond. Biophys Rev. (current issue)

Sanghamitra NJ, Inaba $\mathrm{H}$, Arisaka $\mathrm{F}$, Ohtan WD, Kanamaru S, Kitagawa S, Ueno T (2014) Plasma membrane translocation of a protein needle based on a triple-stranded $\beta$-helix motif. Mol BioSyst 10:2677-2683

Sano K, Asanuma-Date K, Arisaka F, Hattori S, Ogawa H (2007) Changes in glycosylation of vitronectin modulate multimerization and collagen binding during liver regeneration. Glycobiology 17:784-794

Saotome T, Nakamura S, Islam MM, Nakazawa A, Dellarole M, Arisaka F, Kidokoro S, Kuroda Y (2016) Unusual reversible oligomerization of unfolded dengue envelope protein domain 3 at high temperatures and its abolition by a point mutation. Biochemistry 55:4469-4475

Sasahara K (2018) Membrane-mediated amyloid deposition of human islet amyloid polypeptide. Biophys Rev. (current issue)

Sato N, Matsumiya A, Higashino Y, Funaki S, Kitao Y, Oba Y, Inoue R, Arisaka F, Sugiyama M, Urade R (2015) Molecular assembly of wheat gliadins into nanostructures: a small-angle $\mathrm{X}$-ray scattering study of gliadins in distilled water over a wide concentration range. $\mathrm{J}$ Agric Food Chem 63:8715-8721

Sawada N, Nagahara N, Arisaka F, Mitsuoka K, Minami M (2011) Redox and metal-regulated oligomeric state for human porphobilinogen synthase activation. Amino Acids 41:173-180

Sawitri WD, Afidah SN, Nakagawa A, Hase T and Sugiharto B (2018) Identification of UDP-glucose binding site in glycosyltransferase domain of sucrose phosphate synthase from sugarcane (Saccharum officinarum) by structure based site-directed mutagenesis. Biophys Rev. (current issue)

Schellman JA (1975) Macromolecular binding. Biopolymers 14: 999-1018

Schuck P (2000) Size-distribution analysis of macromolecules by sedimentation velocity ultracentrifugation and Lamm equation modeling. Biophys J 78:1606-1619

Schuck P (2018) Congratulations to Prof. Fumio Arisaka on his 70th birthday. Biophys Rev. (current issue)

Seio K, Tokugawa M, Tsunoda H, Ohkubo A, Arisaka F, Sekine M (2013) Assembly of pyrene-modified DNA/RNA duplexes incorporating a G-rich single strand region. Bioorg Med Chem Lett 23:6822-6824

Sekiya T, Hu Y, Kato K, Okuwaki M, Kawaguchi A, and Nagata K (2018) Assembly and remodeling of viral DNA and RNA replicons regulated by cellular molecular chaperones. Biophys Rev. (current issue)

Senda M and Senda T (2018) Anaerobic crystallization of proteins. Biophys Rev. (current issue) 
Serwer P, Wright ET, Demeler B and Jiang W (2018) States of Phage T3/ T7 Capsids: Buoyant Density Centrifugation and Cryo-EM. Biophys Rev. (current issue)

Shapiro JA (1979) Molecular model for the transposition and replication of bacteriophage mu and other transposable elements. Proc Nat Acad Sci USA 76:1933-1937

Shimizu Y, Morii H, Arisaka F, Tanokura M (2005) Stalk region of kinesin-related protein Unc104 has moderate ability to form coiled-coil dimer. Biochem Biophys Res Commun 337:868-874

Soares da Costa TP, Abbott BM, Gendall AR, Panjikar S and Perugini MA (2018) Molecular Evolution of an Oligomeric Biocatalyst Functioning in Lysine Biosynthesis. Biophys Rev. (current issue)

Song JX (2018) Environment-transformable sequence-structure relationship: a general mechanism for proteotoxicity. Biophys Rev. (current issue)

Stille M. and Bryan T. (2012) Imperial Japanese Navy Aircraft Carriers 1921-1945. Osprey Publishing

Straub FB 1943 Actin, II. Studies from the Institute of Medical Chemistry, University of Szeged: Muscular Contraction, Blood Coagulation. 3:23-37

Sugimoto K, Kanamaru S, Iwasaki K, Arisaka F, Yamashita I (2006) Construction of a ball-and-spike protein supramolecule. Angewante Chemie Int Ed 45:2725-2728

Suzuki T, Yasugi M, Arisaka F, Yamagishi A, Oshima T (2001) Adaptation of a thermophilic enzyme, 3-isopropylmalate dehydrogenase, to low temperatures. Protein Eng 14:85-91

Suzuki T, Yasugi M, Arisaka F, Oshima T, Yamagishi A (2002) Coldadaptation mechanism of mutant enzymes of 3-isopropylmalate dehydrogenase from Thermus thermophilus. Protein Eng 15:471-476

Takahashi H, Inagaki E, Fujimoto Y, Kuroishi C, Nodake Y, Nakamura Y, Arisaka F, Yutani K, Kuramitsu S, Yokoyama S, Yamamoto M, Miyano M, Tahirov TH (2004) Structure and implications for the thermal stability of phosphopantetheine adenylyltransferase from Thermus thermophilus. Acta Crystallogr D Biol Crystallogr 60:97-104

Takahashi S., Yoshida A., and Oikawa H. (2018) Hypothesis: structural heterogeneity of the unfolded proteins originating from the coupling of the local clusters and the long-range distance distribution. Biophysical reviews (current issue)

Takeda S (2018) Most of it started with T4 phage and was then taken over. Biophys Rev. (current issue)

Takeda S, Arisaka F, Ishii S, Kyogoku Y (1990) Structural studies of the contractile tail sheath protein of bacteriophage T4. 1 . Conformational change of the tail sheath upon contraction as probed by differential chemical modification. Biochemistry 29:5050-5056

Takeda S, Hoshida K, Arisaka F (1998a) Mapping of functional sites on the primary structure of the tail lysozyme of bacteriophage T4 by mutational analysis. Biochim Biophys Acta 1384:243-252

Takeda S, Sasaki T, Ritani A, Howe MM, Arisaka F (1998b) Discovery of the tail tube gene of bacteriophage mu and sequence analysis of the sheath and tube genes. Biochim Biophys Acta 1399:88-92

Takeda S, Suzuki M, Yamada T, Kageyama M, Arisaka F (2004) Mapping of functional sites on the primary structure of the contractile tail sheath protein of bacteriophage $\mathrm{T} 4$ by mutation analysis. Biochim Biophys Acta 1699:163-171

Takei T, Tsumoto K, Yoshino M, Kojima S, Yazaki K, Ueda T, Takei T, Arisaka F, Miura K (2014) Role of positions e and $g$ in the fibrous assembly formation of an amphipathic $\alpha$-helix-forming polypeptide. Biopolymers 102:260-272

Tamakoshi M, Murakami A, Sugisawa M, Tsuneizumi K, Takeda S, Saheki T, Izumi T, Akiba T, Mitsuoka K, Toh H, Yamashita A, Arisaka F, Hattori M, Oshima T, Yamagishi A (2011) Genomic and proteomic characterization of the large Myoviridae bacteriophage $\phi T M A$ of the extreme thermophile Thermus thermophilus. Bacteriophage 1:152-164

Tayo LL (2017) Stimuli-Responsive Nanocarriers for Intracellular Delivery. Biophys Rev 9:931-940
Toda A, Tanaka H, Kurisu G (2018) Structure atlas of dynein motors at atomic resolution . Biophys Rev. https://doi.org/10.1007/s12551018-0402-y

Tokunaga H, Ishibashi M, Arisaka F, Arai S, Kuroki R, Arakawa T, Tokunaga M (2008) Residue 134 determines the dimer-tetramer assembly of nucleoside diphosphate kinase from moderately halophilic bacteria. FEBS Lett 582:1049-1054

Tschopp J, Arisaka F, van Driel R, Engel J (1979) Purification, characterization and reassembly of the bacteriophage T4D tail sheath protein P18. J Mol Biol 128:247-258

Tsutsui N, Sakamoto T, Arisaka F, Tanokura M, Nagasawa H, Nagata K (2016) Crystal structure of a crustacean hyperglycemic hormone $(\mathrm{CHH})$ precursor suggests structural variety in the C-terminal regions of CHH superfamily members. FEBS J 283:4325-4339

Uchida K, Leiman PG, Arisaka F, Kanamaru S (2014) Structure and properties of the $\mathrm{C}$-terminal $\beta$-helical domain of $\mathrm{VgrG}$ protein from Escherichia Coli O157. J Biochem 155:173-182

Uchiyama S, Noda M and Krayukhina E (2018) Sedimentation velocity analytical ultracentrifugation for characterization of therapeutic antibodies. Biophys Rev. (current issue)

Ueno T, Koshiyama T, Tsuruga T, Goto T, Kanamaru S, Arisaka F, Watanabe Y (2006) Bionanotube tetrapod assembly by in situ synthesis of a gold nanocluster with (Gp5-His6)3 from bacteriophage T4. Angewante Chemie International Edition 45:4508-4512

Unzai S (2018) AUC for structural biology. Biophys Rev. (current issue)

Urade R, Sato N and Sugiyama M (2018) Gliadins from wheat grain: An overview, from primary structure to nanostructures of aggregates. Biophys Rev. (current issue)

Urano F, Hayashi N, Arisaka F, Kurita H, Murata S, Ichinose H (2006) Molecular mechanism for pterin-mediated inactivation of tyrosine hydroxylase: formation of insoluble aggregates of tyrosine hydroxylase. J Biochem 139:625-635

Van Holde KE (1985) Physical biochemistry. Prentice Hall, Englewood Cliffs

van Holde KE, Johnson WC, Ho PS (2006) Principles Physical Biochemistry (Japanese translation by Tanokura M, Arisaka F). Prentice Hall, Upper Saddle River, New Jersey

Van Holde KE, Weischet WO (1978) Boundary analysis of sedimentation-velocity experiments with monodisperse and paucidisperse solutes. Biopolymers 17:1387-1403

Van Holde KE, Blair D, Eldred N, Arisaka F (1977) Association equilibria of Callianassa hemocyanin. In 'structure and function of Haemocyanin'. Springer, Berlin Heidelberg, pp 22-30

Wadahama H, Iwasaki K, Matsusaki M, Nishizawa K, Ishimoto M, Arisaka F, Takagi K, Urade R (2012) Accumulation of $\beta$ conglycinin in soybean cotyledon through the formation of disulfide bonds between $\alpha^{\prime}$ - and $\alpha$-subunits. Plant Physiol 158:1395-1405

Watanabe M, Tanaka Y, Suenaga A, Kuroda M, Yao M, Watanabe N, Arisaka F, Ohta T, Tanaka I, Tsumoto K (2008) Structural basis for multimeric heme complexation through a specific protein-heme interaction: the case of the third neat domain of IsdH from Staphylococcus Aureus. J Biol Chem 283:28649-28659

Wegner A, Engel J (1975) Kinetics of the cooperative association of actin to actin filament. Biophys Chem 3:215-225

Wyman J (1964) Linked functions and reciprocal effects in hemoglobin: a second look. Adv Protein Chem 19:223-286

Yagi S, Akanuma S and Yamagishi A (2018) Creation of artificial protein-protein interactions using $\alpha$-helices as interfaces. Biophys Rev. (current issue)

Yamaguchi K and Kuwata K (2018) Formation and properties of amyloid fibrils of prion protein. Biophys Rev. (current issue)

Yamaguchi M, Ohta E, Takuya M, Watanabe T, Hohsaka T, Yamazaki Y, Kamikubo H and Kataoka M (2018) Statistical description of the denatured structure of a single protein, staphylococcal nuclease, by FRET analysis. Biophys Rev. (current issue) 
Yamasaki K, Urushibata Y, Yamasaki T, Arisaka F, Matsui I (2010) Solution structure of the N-terminal domain of the archaeal Dfamily DNA polymerase small subunit reveals evolutionary relationship to eukaryotic B-family polymerases. FEBS Lett 584: 3370-3375

Yamniuk AP, Newitt JA, Doyle ML, Arisaka F, Giannetti AM, Hensley P, Myszka DG, Schwarz FP, Thomson JA, Eisenstein E (2015) Development of a model protein interaction pair as a benchmarking tool for the quantitative analysis of 2-site protein-protein interactions. J Biomol Technol 26:125-141

Yap ML, Mio K, Ali S, Minton AP, Kanamaru S, Arisaka F (2010a) Sequential assembly of the wedge of the baseplate of phage T4 in the presence and absence of gp11 as monitored by analytical ultracentrifugation. Macromol Biosci 10:808-813

Yap ML, Mio K, Leiman PG, Kanamaru S, Arisaka F (2010b) The baseplate wedges of bacteriophage T4 spontaneously assemble into hubless baseplate-like structure in vitro. J Mol Biol 395:349-360

Yap ML, Klose T, Plevka P, Aksyuk A, Zhang X, Arisaka F, Rossmann MG (2014) Structure of the 3.3MDa, in vitro assembled, hubless bacteriophage T4 baseplate. J Struct Biol 187:95-102

Yap ML, Klose T, Arisaka F, Speir JA, Veesler D, Fokine A, Rossmann MG (2016) Role of bacteriophage T4 baseplate in regulating assembly and infection. Proc Nat Acad Sci U.S.A. 113:2654-2659

Yokoi N, Inaba H, Terauchi M, Stieg AZ, Sanghamitra NJ, Koshiyama T, Yutani K, Kanamaru S, Arisaka F, Hikage T, Suzuki A, Yamane T, Gimzewski JK, Watanabe Y, Kitagawa S, Ueno T (2010) Construction of robust bio-nanotubes using the controlled self-assembly of component proteins of bacteriophage T4. Small 6:1873-1879

Yokoi N, Miura Y, Huang CY, Takatani N, Inaba H, Koshiyama T, Kanamaru S, Arisaka F, Watanabe Y, Kitagawa S, Ueno T (2011) Dual modification of a triple-stranded $\beta$-helix nanotube with Ru and re metal complexes to promote photocatalytic reduction of $\mathrm{CO} 2$. Chem Commun (Camb) 47:2074-2076

Zhao L, Takeda S, Leiman PG, Arisaka F (2000) Stoichiometry and intersubunit interaction of the wedge initiation complex, gp10-gp11, of bacteriophage T4. Biochim Biophys Acta 1479:286-292

Zhao L, Kanamaru S, Chaidirek C, Arisaka F (2003) P15 and P3, the tail completion proteins of bacteriophage $\mathrm{T} 4$, both form hexameric rings. J Bacteriol 185:1693-1700

Zhao H, Ghirlando R, Alfonso C, Arisaka F, Attali I, Bain DL, Bakhtina MM, Becker DF, Bedwell GJ, Bekdemir A, Besong TM, Birck C,
Brautigam CA, Brennerman W, Byron O, Bzowska A, Chaires JB, Chaton CT, Cölfen H, Connaghan KD, Crowley KA, Curth U, Daviter T, Dean WL, Díez AI, Ebel C, Eckert DM, Eisele LE, Eisenstein E, England P, Escalante C, Fagan JA, Fairman R, Finn RM, Fischle W, de la Torre JG, Gor J, Gustafsson H, Hall D, Harding SE, Cifre JG, Herr AB, Howell EE, Isaac RS, Jao SC, Jose D, Kim SJ, Kokona B, Kornblatt JA, Kosek D, Krayukhina E, Krzizike D, Kusznir EA, Kwon H, Larson A, Laue TM, Le Roy A, Leech AP, Lilie H, Luger K, Luque-Ortega JR, Ma J, May CA, Maynard EL, Modrak-Wojcik A, Mok YF, Mücke N, Nagel-Steger L, Narlikar GJ, Noda M, Nourse A, Obsil T, Park CK, Park JK, Pawelek PD, Perdue EE, Perkins SJ, Perugini MA, Peterson CL, Peverelli MG, Piszczek G, Prag G, Prevelige PE, Raynal BD, Rezabkova L, Richter K, Ringel AE, Rosenberg R, Rowe AJ, Rufer AC, Scott DJ, Seravalli JG, Solovyova AS, Song R, Staunton D, Stoddard C, Stott K, Strauss HM, Streicher WW, Sumida JP, Swygert SG, Szczepanowski RH, Tessmer I, Toth RT 4th, Tripathy A, Uchiyama S, Uebel SF, Unzai S, Gruber AV, von Hippel PH, Wandrey C, Wang SH, Weitzel SE, Wielgus-Kutrowska B, Wolberger C, Wolff M, Wright E, Wu YS, Wubben JM, Schuck P (2015) A multilaboratory comparison of calibration accuracy and the performance of external references in analytical ultracentrifugation. PLoS One 10:e126420

Zhao R, So M, Maat H, Ray NJ, Arisaka F, Goto Y, Carver JA, Hall D (2016) Measurement of amyloid formation by turbidity assay-seeing through the cloud. Biophys Rev 8:445-471

\section{Note added in proof}

The three Editors of this special issue would like to offer our sincere apologies to Assoc. Prof. Lemmuel Tayo of Mapua University (Philippines) whose article was accidentally included in the preceding issue of Biophysical Reviews (Tayo 2017). Through their long-term collaboration as fellow council members of the Asia Pacific Protein Association, Assoc. Prof. Tayo's article should have been included in the body of review articles collected in this issue in honour of Prof. Arisaka's 70th birthday (indeed Assoc. Prof. Tayo can be seen in the second row of Fig. 11 at the inaugural meeting of the APPA Council) 